\title{
Regulatory T Cell Induced by Poria cocos Bark Exert Therapeutic Effects in Murine Models of Atopic Dermatitis and Food Allergy
}

\author{
Min-Jung Bae, ${ }^{1}$ Hye-Jeong See, ${ }^{2}$ Gyeyoung Choi, ${ }^{3}$ Chang-Yuil Kang, \\ Dong-Hwa Shon, ${ }^{2,5}$ and Hee Soon Shin ${ }^{2,5}$ \\ ${ }^{1}$ Institutes of Entrepreneurial BioConvergence, Seoul National University, Seoul 151-742, Republic of Korea \\ ${ }^{2}$ Division of Nutrition and Metabolism Research, Korea Food Research Institute, \\ Bundang-gu, Seongnam-si, Gyeonggi-do 463-746, Republic of Korea \\ ${ }^{3}$ WCU Department of Molecular Medicine and Biopharmaceutical Science, Graduate School of Convergence Science and \\ Technology and College of Pharmacy, Seoul National University, Seoul 151-742, Republic of Korea \\ ${ }^{4}$ Laboratory of Immunology, Research Institute of Pharmaceutical Sciences, College of Pharmacy, Seoul National University, \\ Seoul 151-742, Republic of Korea \\ ${ }^{5}$ Food Biotechnology Program, Korea University of Science and Technology, Daejeon 305-350, Republic of Korea
}

Correspondence should be addressed to Hee Soon Shin; hsshin@kfri.re.kr

Received 18 March 2016; Revised 9 May 2016; Accepted 10 May 2016

Academic Editor: Kyung H. Kim

Copyright (C) 2016 Min-Jung Bae et al. This is an open access article distributed under the Creative Commons Attribution License, which permits unrestricted use, distribution, and reproduction in any medium, provided the original work is properly cited.

\begin{abstract}
The prevalence of allergic disorders including atopic dermatitis (AD) and food allergy (FA) has increased dramatically in pediatric populations, but there is no effective drug available for their management. Therefore, trials are required for the development of safe therapeutic agents such as herbal medicines. We determined whether orally administered Poria cocos bark (PCB) extract could exert immunosuppressive effects on allergic and inflammatory symptoms of $\mathrm{AD}$ and FA. For both $\mathrm{AD}$, which was induced using house dust mite extract, and FA, which was induced by exposure to ovalbumin, model mice were orally treated with PCB extract for 62 days and 18 days, respectively. We also investigated the inductive effect of PCB extract on the generation and maintenance of Foxp $3^{+} \mathrm{CD}^{+}$regulatory T cells (Tregs). The symptoms of $\mathrm{AD}$ and FA were ameliorated by the administration of PCB extract. Furthermore, PCB extract inhibited the Th2-related cytokines and increased the population of Foxp $3^{+} \mathrm{CD} 4^{+}$Tregs in both $\mathrm{AD}$ and FA models. In ex vivo experiments, PCB extract promoted the functional differentiation of Foxp $3^{+} \mathrm{CD} 4^{+}$Tregs, which is dependent on aryl hydrocarbon receptor activation. Thus, PCB extract has potential as an oral immune suppressor for the treatment of AD and FA through the generation of Tregs.
\end{abstract}

\section{Introduction}

Hypersensitivity diseases called allergic disorders result from the breakdown of natural tolerance, and their prevalence has increased worldwide. In particular, the incidence of atopic dermatitis (AD) and food allergy (FA) is increasing and they have been estimated to affect $10-20 \%$ and $5-6 \%$ of the pediatric population, respectively $[1,2]$.

$\mathrm{AD}$ is a chronic and allergic inflammatory skin disease [3] caused by both genetic and environmental factors [2]. In general, $\mathrm{AD}$ develops owing to sensitization of allergens such as food and house dust mite (HDM), and then abnormal patterns in the immune system contribute to the pathogenesis and development of $\mathrm{AD}$ [4]. In particular, T-helper type 2(Th2-) dominant immune responses play key roles in $\mathrm{AD}$. The number of various immune cells such as T lymphocytes, macrophages, eosinophils, and mast cells increases in $\mathrm{AD}$ and these cells infiltrate to form skin lesions. Therefore, these cells could be targeted to treat or prevent $\mathrm{AD}[5,6]$.

FA is a hypersensitivity disorder caused by substances derived from foods and develops when the immune system reacts to food allergens after ingestion. Food allergens such 
as ovalbumin (OVA) and ovomucoid from eggs, caseins and beta-lactoglobulin from milk, peanut agglutinin from peanuts, and tropomyosins from shrimp are known [7]. Mild allergic reactions are common, causing symptoms such as diarrhea, hypotension, pruritus, and vomiting [8]. However, in severe cases, lethal anaphylactic shock can occur [9].

Regulatory T (Treg) cells and Forkhead box P3- (Foxp3-) expressing $\mathrm{CD} 4^{+} \mathrm{T}$ cells are important for the functions of the immune system. Since functional Foxp $3^{+} \mathrm{CD} 4^{+} \mathrm{T}$ cells have immune suppressive activities, they are able to attenuate hyperimmune responses and the inflammatory, allergic, and autoimmune disorders due to these responses [10-12]. Therefore, the induction of Foxp3 expression in these diseases may contribute to the induction of immune tolerance by generation of regulatory $\mathrm{T}$ cells [13] and suppress the symptoms of HDM-induced AD and OVA-induced FA.

The generation of Foxp $3^{+}$Tregs is driven by transforming growth factor- $\beta$ (TGF- $\beta$ ) and interleukin-2 (IL-2) $[14,15]$. Recent studies concluded that Treg generation is promoted by ligand-dependent activity and the expression of aryl hydrocarbon receptor (AhR), which is recruited to the Foxp3 promoter [16]. Natural AhR ligands can be isolated or synthesized from dietary compounds including curcumin, indirubin, or indole-3-carbinol (I3C), as well as 2,3,7,8-tetrachlorodibenzo- $p$-dioxin [17-19]. The finding that natural ligands affect the induction of Foxp $3^{+}$Tregs via AhR activation is receiving increased attention [20, 21]. Therefore, these dietary AhR ligands might influence the onset of $\mathrm{AD}$ and FA.

Poria cocos is an edible basidiomycete that grows on pine tree roots; it is widely used as a traditional medicine in East Asia. The P. cocos extract has beneficial effects on inflammation and cancer [22]. Recent studies have focused on the beneficial effects of $P$. cocos derivatives on immune function [23-25]. In particular, the $P$. cocos bark (PCB) extracts include triterpenoid compounds or/and ergosterol, which is used to treat inflammatory diseases including rheumatoid arthritis and systemic lupus erythematosus and symptoms associated with ulcerative colitis [26, 27]. However, the scientific evidence for the antiallergic effects of PCB extract is not clear.

The aim of this study was to determine whether PCB extract exerts an effect on the generation and maintenance of Foxp $3^{+} \mathrm{CD}^{+}$Tregs. Furthermore, we investigated whether orally administered PCB extracts could improve allergic symptoms in murine models of HDM-induced AD and OVAinduced FA.

\section{Materials and Methods}

2.1. Sample Preparation. The PCB extract used in this study was from the Plant Extract Bank of Korea (Plant Diversity Research Center of the 21st Century Frontier Research Program). Voucher specimens were deposited at the herbarium of the Plant Extract Bank of Korea (Daejeon, Korea). Ethyl alcohol (EtOH; 95\%) dried extracts were dissolved in saline (Sigma-Aldrich, St. Louis, MO) and dimethylsulfoxide (DMSO) before use. Endotoxin level in PCB extract using Pyrogent Plus assay kit (Lonza, Hopkinton, Massachusetts) was found to be below $0.06 \mathrm{EU} / \mathrm{mL}$, which is the limit of sensitivity for this kit.

2.2. Animal Experiments. Four-week-old female BALB/c mice $(18-20 \mathrm{~g})$ were purchased from OrientBio Inc. (Kyeonggi, Korea) and housed at $23 \pm 2^{\circ} \mathrm{C}$ with a $12 \mathrm{~h}$ light/dark cycle and free access to food and water. This study was carried out in strict accordance with the recommendations in the Guide for the Care and Use of Laboratory Animals of the National Institutes of Health with special attention to minimizing animal pain. The study protocol was approved by the Animal Care and Use Committee of Korea Food Research Institute (Approval Number: KFRI-M14018). No animals were sacrificed or died as a result of the experiment before day 35. Six-week-old female Foxp3-GFP C57BL/6 mice were previously described [28]. These mice were housed at $23 \pm 2^{\circ} \mathrm{C}$ with a $12 \mathrm{~h}$ light/dark cycle and free access to food and water. All experimental procedures were performed in compliance with the guidelines set by the University Animal Care and Use Committee at Seoul National University with special attention to minimizing animal pain. The study protocol was approved by the Seoul National University Institutional Animal Care and Use Committee (Approval Number: SNU-130807-4-1).

2.3. Cell Purification and Sorting. Naïve $\mathrm{CD}^{+} \mathrm{T}$ cells from $\mathrm{BALB} / \mathrm{c}$ mice were isolated using a magnetic-activated cell sorting (MACS) CD4 ${ }^{+} \mathrm{CD}_{2} \mathrm{~L}^{+} \mathrm{T}$ cell isolation kit (Miltenyi Biotec, Bergisch-Gladbach, Germany) following the manufacturer's instructions. T cell-depleted cells, as antigenpresenting cells (APCs), were prepared from the spleen cells of BALB/c mice and mLN cells by negative selection using MACS. The purity of isolated cells was confirmed using FACS. Foxp $3^{+} \mathrm{CD}^{+} \mathrm{T}$ cells were sorted from Foxp3eGFP to $>99 \%$ purity using FACS Aria III (BD Biosciences) with anti-CD4, anti-CD45RB, and anti-CD25 antibodies (eBioscience). On day 3, the Treg population was isolated based on CD4 and Foxp3-eGFP expression using FACS.

\subsection{Functional Differentiation of Nä̈ve $C D 4^{+} T$ Cells. Naïve} $\mathrm{BALB} / \mathrm{c} \mathrm{CD} 4^{+} \mathrm{T}$ cells $\left(1 \times 10^{6}\right.$ cells/well $)$ were cultured in 96-well plates in the presence of $0-100 \mathrm{mg} / \mathrm{mL}$ PCB extract in $0.1 \%$ DMSO. $\mathrm{T}$ cell receptor (TCR) stimulation was performed using $10 \mu \mathrm{g} / \mathrm{mL}$ plate-bound anti-CD3 (BioLegend, San Diego, CA, 17A2) and $2 \mu \mathrm{g} / \mathrm{mL}$ soluble anti-CD28 (BioLegend, San Diego, CA, 37.51) antibodies. To analyze the $\mathrm{CFSE}^{+}$population that was converted by Foxp $3^{+} \mathrm{CD} 4^{+}$ Treg, $\mathrm{CD}^{+}{ }^{\mathrm{CD}} 62 \mathrm{~L}^{+} \mathrm{T}$ cells labeled with $5 \mu \mathrm{M}$ CFSE (Life Technologies, Australia) were cocultured with $\mathrm{CD}^{+}$cells that had been precultured in the presence or absence of PCB extract and/or TCR stimulation for 3 days. The CFSE ${ }^{+}$ population was then analyzed using FACS.

2.5. Induction of $A D$ by Administration of HDM Extract in the Ear. The mice were divided into naive $(n=8)$, sham $(n=11), \operatorname{PCB}(n=8)$, and dexamethasone $(n=6)$ groups. To induce $\mathrm{AD}$, the surfaces of both ear lobes of the mice were stripped using surgical tape (Shinshin Pharm., 


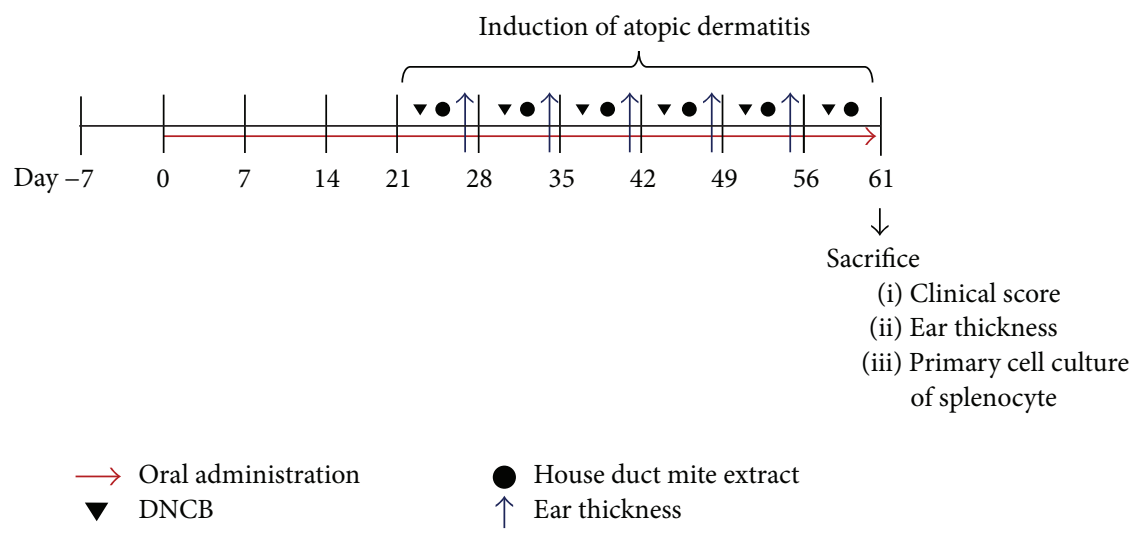

(a)

$\longrightarrow$ Oral administratio
$\begin{aligned} & \text { Immunization } \\ & \text { (Imm): }\end{aligned}$
i.p. OVA $(20 \mu \mathrm{g})$
with Alum $(2 \mu \mathrm{g})$
challenge
(Cha):
Oral OVA $(50 \mathrm{mg})$

\section{$17 \quad 20$}

(a)
(i) Clinical score
(ii) Ear thickness
i) Primary cell culture
of splenocyte

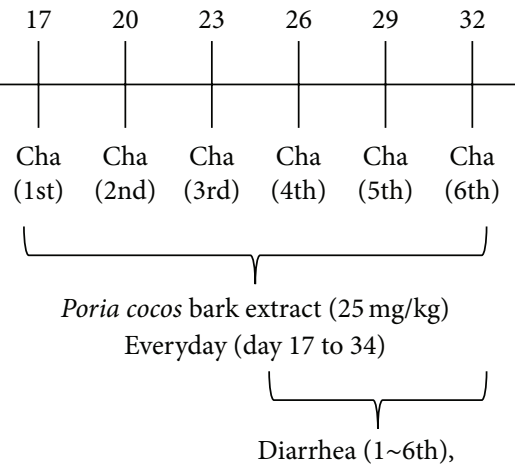

anaphylaxis symptoms (1 6th)

rectal temperature (6th),

( 0 to 1 hour after challenges)

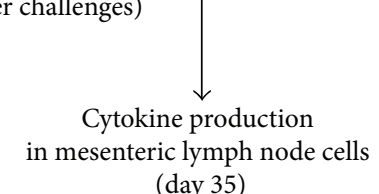

(day 35)

(b)

FIGURE 1: Experimental designs for inductions of atopic dermatitis and food allergy. (a) Five-week-old female BALB/c mice were divided into naïve $(n=7)$, sham $(n=12)$, PCB $(n=12)$, and dexamethasone $(n=8)$ groups. $25 \mathrm{mg} / \mathrm{kg}$ of PCB extract was orally administrated from day 0 to 61 . For induction of atopic dermatitis, each $1 \%$ DNCB and $10 \mathrm{mg} / \mathrm{mL}$ of HDM extract was applied to each ear once a week from day 21 (total six times). (b) Six-week-old female BALB/c mice were divided into naïve $(n=5)$, sham $(n=9)$, PCB $(n=9)$, and dexamethasone $(n=5)$ groups. To induce food allergies, mice were immunized with $20 \mu \mathrm{g}$ OVA and $2 \mathrm{mg}$ Imject Alum by intraperitoneal (i.p.) injection on day 0 . From day 17 , mice were orally challenged with $50 \mathrm{mg}$ OVA in saline every 3 days, for a total of six times. Next, $25 \mathrm{mg} / \mathrm{kg}$ PCB extract was administered orally daily from day 17 to 34 .

Korea). After stripping, $20 \mu \mathrm{L}$ of $1 \%$ 2,4-dinitrochlorobenzene (DNCB) (Sigma-Aldrich, St. Louis, MO, USA) dissolved in acetone/olive oil solution (acetone: olive oil $=1: 3$ ) was painted on each ear lobe. After 2 days, $20 \mu \mathrm{L}$ of HDM extract $(10 \mathrm{mg} / \mathrm{mL}$, Dermatophagoides farinae, GREER Source Materials, Lenoir, NC, USA) dissolved in phosphate-buffered saline (PBS) was reapplied on each ear lobe. Challenges with DNCB and HDM extract were repeated once a week alternatively until 6 weeks; the naïve group was challenged with only tape stripping and PBS. PCB extract ( $25 \mathrm{mg} / \mathrm{kg}$ ) was administered orally daily for 3 weeks before $\mathrm{AD}$ was induced by HDM and DNCB (Figure 1(a)). Clinical score was calculated using modified criteria [29]. Briefly, each ear region was assessed separately for erythema/edema, scaling/dryness, and excoriation/hemorrhage, and the average degree of severity in each ear region was assigned a score of $0,1,2$, or 3 , which indicated none, mild, moderate, and severe, respectively.

2.6. Analysis of Histological Changes in the Ear. Ear lesions of each group were fixed with $10 \%$ formalin solution and embedded in paraffin. They were then cut into $6 \mu \mathrm{m}$ thick sections and stained with hematoxylin (Sigma-Aldrich, St. Louis, MO, USA) and eosin (Sigma-Aldrich, St. Louis, MO, USA) solution (H\&E). H\&E staining was performed according to standard procedures (IHC World, Online Information Center for Histochemistry; http://www.ihcworld.com/). All histologic analyses were performed by a professional pathologist at the College of Veterinary Medicine, Seoul National 
University. Analysis of stained sections was performed using a microscope at 100x and 200x magnification.

2.7. Isolation and Analysis of Infiltrated Cells in the Ears. Ear tissues were removed and placed in $1.0 \mathrm{mmol} / \mathrm{L}$ EDTA in RPMI 1640 medium. The ear tissues and solution were stirred in Erlenmeyer flasks for $20 \mathrm{~min}$ at room temperature. After stirring, the ear tissues were minced with experimental scissors and were rinsed with serum-free RPMI 1640 medium. The ear tissues were then incubated in $0.5 \mathrm{mg} / \mathrm{mL}$ collagenase type 1 (Sigma-Aldrich, St. Louis, MO, USA) in RPMI 1640 medium with slow rotation (130 rpm). After incubation, the solution containing ear cells was rinsed with cold PBS and passed through a $70 \mathrm{~mm}$ cell strainer. The filtered solution was centrifuged at $1300 \mathrm{rpm}$ for $5 \mathrm{~min}$. Cells were gathered and suspended in HBSS containing 10\% FBS, $10 \%$ sodium azide, and $8 \%$ sodium bicarbonate. Infiltrated cells in ears were confirmed by flow cytometry. Surface molecules were stained with anti-CD4 (FITC), anti-CD8 (APC/Cy7), anti-CD11c (PE), anti-CD11b (APC), and antiCD45R (PerCP/Cy5.5) (all from eBioscience, San Diego, CA, USA) for $30 \mathrm{~min}$. Flow cytometry analysis was performed using BD Canto II instrument (BD Biosciences, San Diego, CA, USA).

2.8. Induction of the Anaphylactic Response by the Oral Administration of OVA. Mice were divided into naïve ( $n=$ 5), sham $(n=9)$, PCB $(n=9)$, and dexamethasone $(n=5)$ groups. To induce an allergic response, mice were sensitized with $20 \mu \mathrm{g}$ OVA in $2 \mathrm{mg} / \mathrm{mL}$ Imject Alum (Pierce, Rockford, IL) by intraperitoneal (i.p.) injection on day 0. Mice were then orally challenged with $50 \mathrm{mg}$ OVA in saline every 3 days from day 17 for a total of six times. PCB extract $(25 \mathrm{mg} / \mathrm{kg}$ ) was administered orally daily from day 17 to 34 (Figure 1(b)). Diarrhea, anaphylaxis, and rectal temperature were measured as food allergy symptoms. To define diarrhea, the state of murine feces was observed and evaluated by visually monitoring once every 15 minutes for 1 hour after OVA challenge.

The criteria of diarrhea are the formlessness of stool and liquid shape (>80\% water). The frequency, amount, and volume of stool were not used as an index showing a state of diarrhea. Temperature changes were measured with a rectal temperature probe (RET3) coupled to the Physitemp Thermalert Model TH-5 (Physitemp, Clifton, NJ). After OVA challenge, temperatures were measured every 15 minutes. Symptom scores were determined according to previously detailed criteria [30].

2.9. Measurement of Cytokine Levels Using ELISA. The mesenteric lymph node (mLN) from each mouse was removed aseptically. The mLNs were then homogenized into single-celled suspensions; $5 \times 10^{6}$ cells $/ \mathrm{mL}$ were added to RPMI medium, and cell viability was determined using trypan blue dye exclusion. Cells $(200 \mu \mathrm{L} /$ well $)$ were cultured in the presence or absence of OVA $(100 \mu \mathrm{g} / \mathrm{mL})$ at $37^{\circ} \mathrm{C}$ for $72 \mathrm{~h}$ in a humidified incubator with $5 \% \mathrm{CO}_{2}$ and $95 \%$ air. Cytokine assay kits (interferon $\gamma[$ IFN- $\gamma]$, IL-4, IL-5,
IL-10, and IL-13, BD Pharmingen, San Diego, CA, and IL-17 and TGF- $\beta, \mathrm{R} \& \mathrm{D}$ Systems, Minneapolis, MN) were used to quantify cytokines following the manufacturer's instructions. The absorbance at $450 \mathrm{~nm}$ was measured using a microplate reader (Molecular Devices, Sunnyvale, CA).

2.10. Immunofluorescence Staining. To stain Foxp3 intracellularly, cells were washed in fluorescence-activated cell sorting (FACS) buffer ( $1 \%$ fetal calf serum and $0.1 \% \mathrm{NaN}_{3}$ in PBS) and incubated with anti-CD16/32 antibody $2.4 \mathrm{G} 2$ for $5 \mathrm{~min}$ at $4^{\circ} \mathrm{C}$ to block Fc receptors (clone: 2.4G2) (BD Pharmingen, San Diego, CA). Surface CD4 molecules were stained with Phycoerythrin- (PE-) labeled anti-CD4 (clone: H129.19) (BioLegend, San Diego, CA) for $30 \mathrm{~min}$ at $4^{\circ} \mathrm{C}$. The cells were then fixed and permeabilized using Foxp3 fixation/permeabilization concentrate and diluent (BD Biosciences, San Jose, CA) for $1 \mathrm{~h}$ at $4^{\circ} \mathrm{C}$. After Fc receptors were blocked for $15 \mathrm{~min}$, cells were stained using peridinin chlorophyll-a protein-Cy5.5- (PerCP-Cy5.5-) labeled antiFoxp3 (clone: FJK-16s) (eBioscience, San Diego, CA) in FACS buffer at $4^{\circ} \mathrm{C}$ for $30 \mathrm{~min}$. Data were acquired by flow cytometry using BD FACSCanto II (BD Biosciences) and analyzed using FlowJo software (Treestar, San Carlos, CA).

2.11. Quantitative Real-Time Reverse Transcription-Polymerase Chain Reaction (RT-PCR). RNA from spleens and mLNs was extracted and purified using the RNeasy Mini Kit (Qiagen, Hilden, Germany), and cDNA was synthesized using the QuantiTect Reverse Transcription Kit (Qiagen). RT-PCR was performed in a Rotor-Gene Q 2plex System (Qiagen) as follows: $10 \mathrm{~min}$ at $95^{\circ} \mathrm{C}$, followed by 45 cycles of $30 \mathrm{~s}$ at $95^{\circ} \mathrm{C}$ and $30 \mathrm{~s}$ at $62^{\circ} \mathrm{C}$. The Assays-on-Demand kit (Qiagen) was used to analyze the expression of HPRT (housekeeping gene), Foxp3, CTLA-4, AhR, and Granzyme B (GranB). The sequences of the primers used are provided in Table 1. HPRT was used to normalize mRNA expression. The data are shown as relative delta delta CT $(\Delta \Delta \mathrm{CT})$; the fold-induction of each gene was calculated as follows: $\Delta$ Threshold cycle $(\Delta \mathrm{Ct})=(\mathrm{Ct}$ of target mRNA $)-(\mathrm{Ct}$ of HPRT $) ; \Delta \Delta \mathrm{Ct}=(\Delta \mathrm{Ct}$ of mRNA in target gene $)-(\Delta \mathrm{Ct}$ of $\mathrm{mRNA}$ in control gene); fold-induction $=2^{-\Delta \Delta \mathrm{Ct}}$.

2.12. Statistical Analysis. Data are presented as mean \pm standard deviation (SD) of triplicate measurements. Differences between experimental data were analyzed using ANOVA followed by F-protected Fisher's least significant difference test, unpaired $t$-test, or one-way repeated measures of ANOVA followed by Tukey's or Dunnett's post hoc test. ND equals not detected. Statistical differences were presented as ${ }^{*} P<0.05$, ${ }^{* *} P<0.01$, and ${ }^{* * *} P<0.001$.

\section{Results}

3.1. Effects of PCB Extract on the Symptoms of HDM-Induced $A D$. In this study, we investigated the antiallergic effects of $\mathrm{PCB}$ extract in a mouse model of AD. The mice were orally administered with PCB extract at a dose of $25 \mathrm{mg} / \mathrm{kg}$ daily for 9 weeks. Ear thickness was evaluated on the day after the HDM challenge every week for 6 weeks. We found that 
TAble 1: Primer sequences used in this study.

\begin{tabular}{lll}
\hline Gene & Primer & Sequence \\
\hline \multirow{2}{*}{ Hypoxanthine-guanine phosphoribosyl transferase } & Sense & $5^{\prime}$-CTGGTGAAAAGGACCTCTCG-3 $^{\prime}$ \\
\hline \multirow{2}{*}{ Forkhead box P3 } & Antisense & $5^{\prime}$-TGAAGTACTCATTATAGTCAAGGGCA-3' $^{\prime}$ \\
\hline \multirow{2}{*}{ Cytotoxic T-lymphocyte antigen 4} & Sense & $5^{\prime}$-CAGCTGCCTACAGTGCCCCTAG-3' \\
& Antisense & $5^{\prime}$-CATTTGCCAGCAGTGGGTAG-3' \\
\hline \multirow{2}{*}{ Granzyme B } & Sense & $5^{\prime}$-AGA ACC ATG CCC GGA TTC TG-3' \\
\hline \multirow{2}{*}{ Aryl hydrocarbon receptor } & Antisense & $5^{\prime}$-CAT CTT GCT CAA AGA AAC AGC AG-3' \\
& Sense & $5^{\prime}$-CTC CTA AAG CTG AAG AGT AAG G-3' \\
& Antisense & $5^{\prime}$-TTT AAA GTA GGA CTC ACA CTC CC-3' \\
\hline
\end{tabular}

PCB extract ameliorated ear thickness and epidermis thickness in models of HDM-induced AD (Figures 2(a)-2(c)). Furthermore, the clinical scores for criteria including erythema/edema, scaling/dryness, and excoriation/hemorrhage significantly reduced to $3.2 \pm 1.0$ points in the PCB extract group compared to $4.9 \pm 1.0$ points in the sham group (Figure 2(d)). We also examined the immune cells that infiltrated the ear in the $\mathrm{AD}$ models. The results indicated that, in ears of animals of the sham group, HDM treatment induced the infiltration of various immune cells such as $\mathrm{CD} 4^{+}$ (T-helper cells), $\mathrm{CD}^{+}$(cytotoxic T cells), B220 ${ }^{+}$(B cells), $\mathrm{CD}_{11 b^{+}}$(macrophages), and CD11c ${ }^{+}$(dendritic cells) cells. However, the administration of PCB extract significantly reduced the infiltration of all these immune cells in the ears of animals in the PCB group (Figure 3(a)).

We next investigated how the PCB extract affected the Th2-related immune response in lymph nodes such as the spleen, mesenteric lymph node (mLN), and draining lymph node (dLN). The HDM-induced Th2-mediated immune responses were suppressed by the administration of PCB extract in each lymph node. In particular, HDM challenge strongly induced IL-4 production in the dLN, which was decreased by treatment with the PCB extract (Figure 3(b)). Meanwhile, administration of PCB extract enhanced the production of IL-10, which is a known anti-inflammatory cytokine in dLN. Since the PCB extract suppressed IL4 production, enhanced IL-10 production in the lymph nodes, and decreased the population of immune cells in the inflammatory region, we investigated the induction of Tregs by analyzing the population of $\mathrm{CD}^{+} \mathrm{Foxp}^{+} \mathrm{T}$ cells. We found that the administration of $\mathrm{PCB}$ extract promoted the expression of Foxp3 on $\mathrm{CD}^{+}{ }^{+} \mathrm{T}$ cells in the dLN isolated from AD models (Figure 3(d)). These results demonstrated that the administration of $\mathrm{PCB}$ extract was able to attenuate the symptoms of AD by inducing Tregs in a mouse model of AD.

3.2. Effects of PCB Extract on the Response to OVA-Induced Food Allergies. In this study, we investigated antiallergic effects of PCB extract in a mouse model of food allergy. We treated mice with PCB extract $(25 \mathrm{mg} / \mathrm{kg})$ on a daily basis by oral gavage. Food allergy symptoms were induced by oral challenges with OVA, and the following symptoms were evaluated. Any of the groups did not reach death by anaphylactic shock. Severe food allergy symptoms were observed in the sham group (scores: diarrhea, 3; anaphylactic response, 2.7) after the sixth oral challenge on day 34. On the contrary, OVA-induced diarrhea symptoms and the anaphylactic response were noticeably suppressed to 2 points and 1.3 in the PCB-treated group, respectively (Figures $4(\mathrm{a})-4(\mathrm{~d})$ ). Moreover, rectal temperature in the sham group decreased by $-7.15^{\circ} \mathrm{C}$ compared with naïve mice. However, PCB extract treatment significantly ameliorated the OVAinduced decrease in rectal temperature to $-2.65^{\circ} \mathrm{C}$ compared with control (Figure 4(e)). Although Dex completely blocked the food allergy symptoms, these mice group showed significant side effects of glucocorticoid, including serious size loss of splenocyte and mLN, and reduction of body weight by more than $7 \%$. In contrast, PCB-treated group showed increase of body weights by more than $7 \%$ and no significant side effects (Figure 4(f)). This suggests that the oral administration of PCB extract attenuated food allergies by inhibiting diarrhea and the anaphylactic response without side effects.

To prove the mechanism of how PCB controls food allergies, we next assessed cytokine expression in mLNs isolated from mice with OVA-induced food allergies. The Th2-related cytokines IL-4, IL-5, and IL-13 were increased in mLNs from food allergy-induced mice. However, this increase was inhibited significantly by treatment with PCB extract (Figures 5(a)-5(c)). In contrast, PCB treatment increased significantly in the TGF- $\beta$ production which modulates the differentiation of T cells to Tregs (Figure 5(d)). Moreover, the PCB extract significantly increased the Foxp $3^{+} \mathrm{CD} 4^{+}$Treg population in comparison with sham group (Figure 5(e)). This suggests that PCB extract regulates the abnormal Th2 dominance after allergic responses to food by increasing Tregs.

3.3. PCB Extracts Induced the Generation and Maintenance of Functional Foxp $3^{+} \mathrm{CD} 4^{+}$Tregs. To determine how PCB extract increased Foxp $3^{+} \mathrm{CD} 4^{+}$Tregs specifically, $\mathrm{CD}^{+}{ }^{+} \mathrm{CD} 62 \mathrm{~L}^{+}$naïve $\mathrm{T}$ cells were cotreated with TCR stimulation using anti-CD3/-CD28 mAbs or anti-CD3/APCs in the presence of PCB. The Foxp $3^{+} \mathrm{CD}^{+} \mathrm{T}$ cell population in mLNs and splenocytes was then measured using FACS. Compared with control, PCB extract significantly increased 


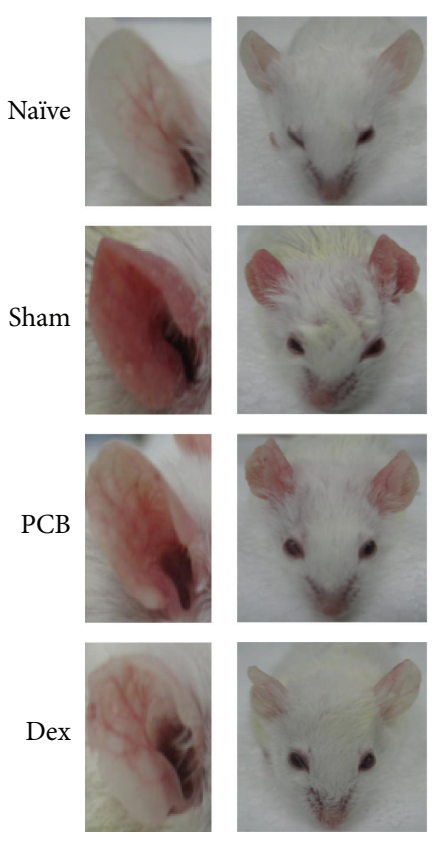

(a)
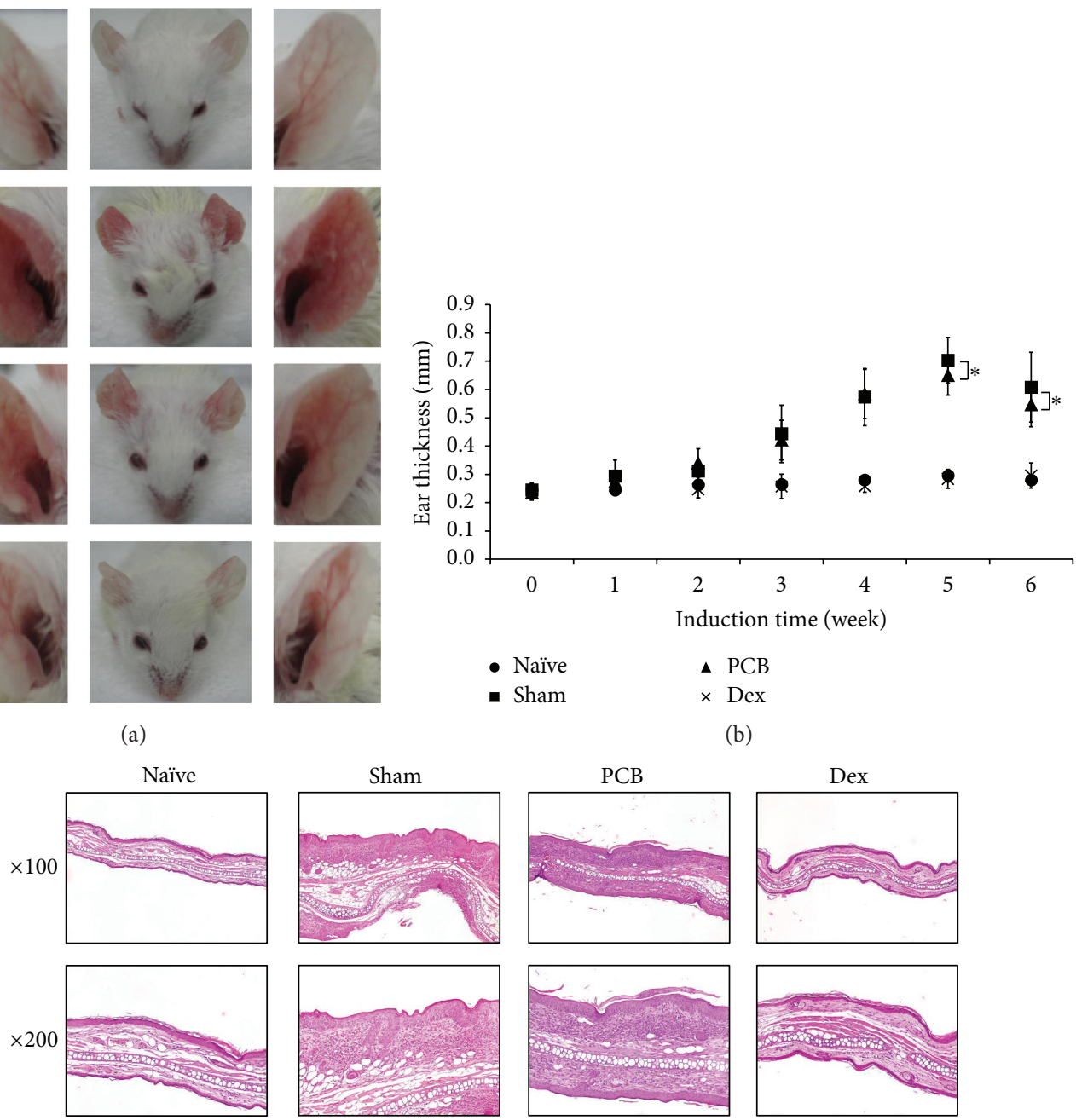

(b)
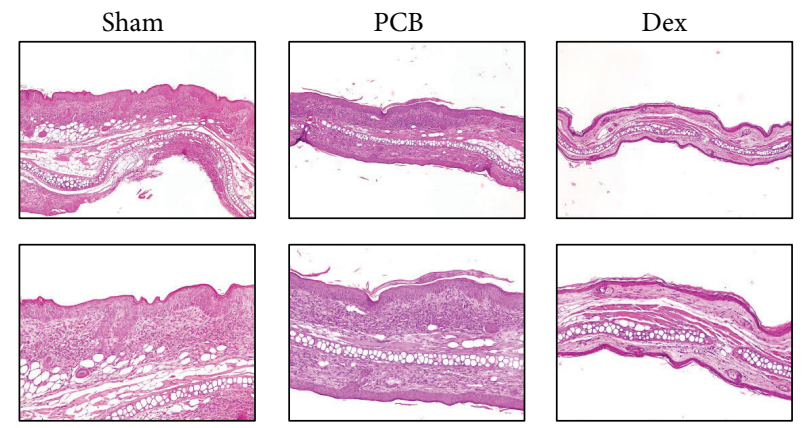

(c)

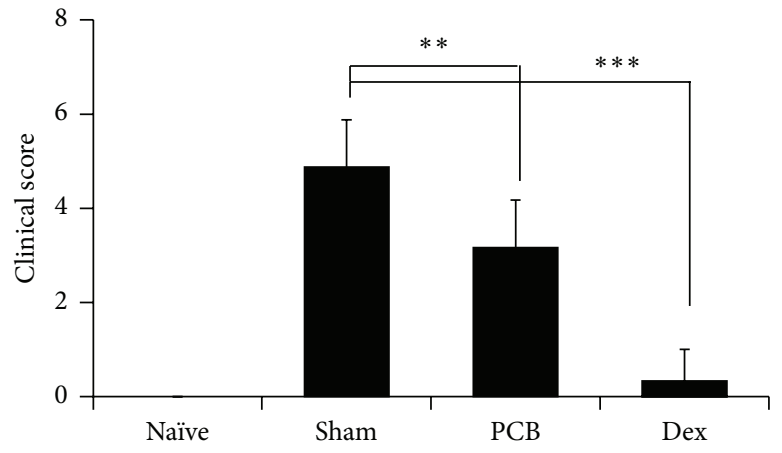

(d)

Figure 2: PCB extract alleviates the symptoms of DNCB/HDM-induced-atopic dermatitis. (a) Typical photographs of ear lesions developed by the treatments of DNCB and HDM on day 62. (b) Ear thickness was measured using digital thickness gauge on next day after HDM treatment from first challenge to sixth. (c) Ear lesions isolated from mice were fixed with $10 \%$ formalin solution and embedded in paraffin. To evaluate epidermal thickness and infiltrated inflammatory cells, H\&E staining was performed and observed using a microscope at 100x and 200x magnification. (d) Clinical score was determined by criteria such as erythema/edema, scaling/dryness, and excoriation/hemorrhage to evaluate degree of severity in each ear lesion on day 62. Data are presented as the mean \pm standard deviation (SD) of triplicate determinations and were analyzed using unpaired $t$-test. ${ }^{*} P<0.05,{ }^{* *} P<0.01$, and ${ }^{* * *} P<0.001$ versus sham group. 


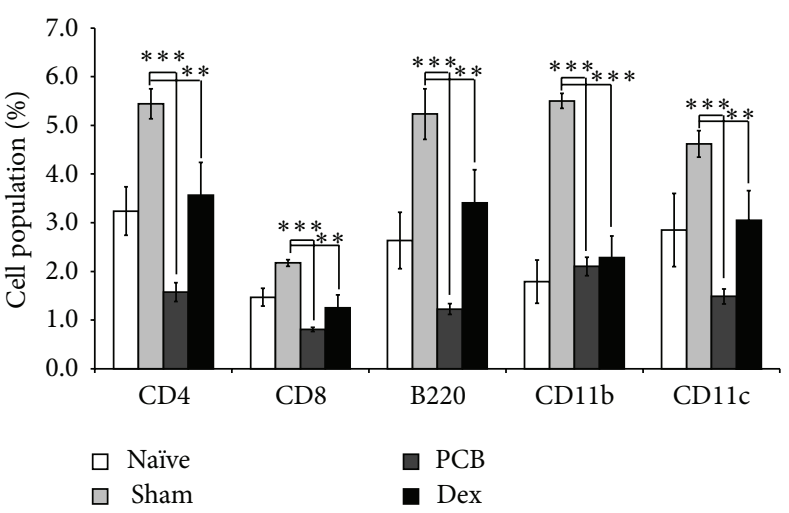

(a)

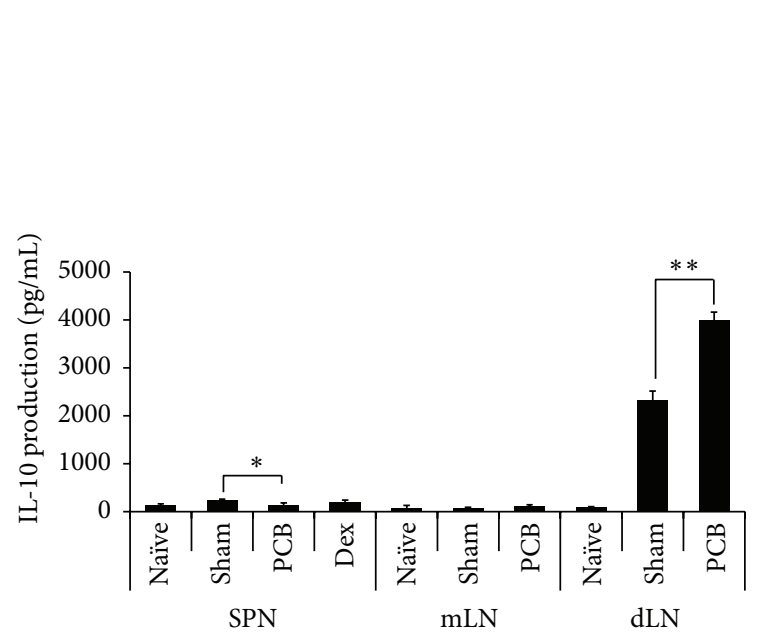

(c)

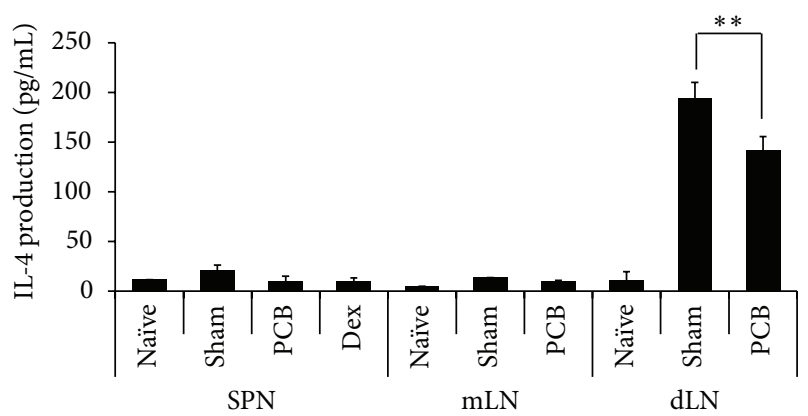

(b)

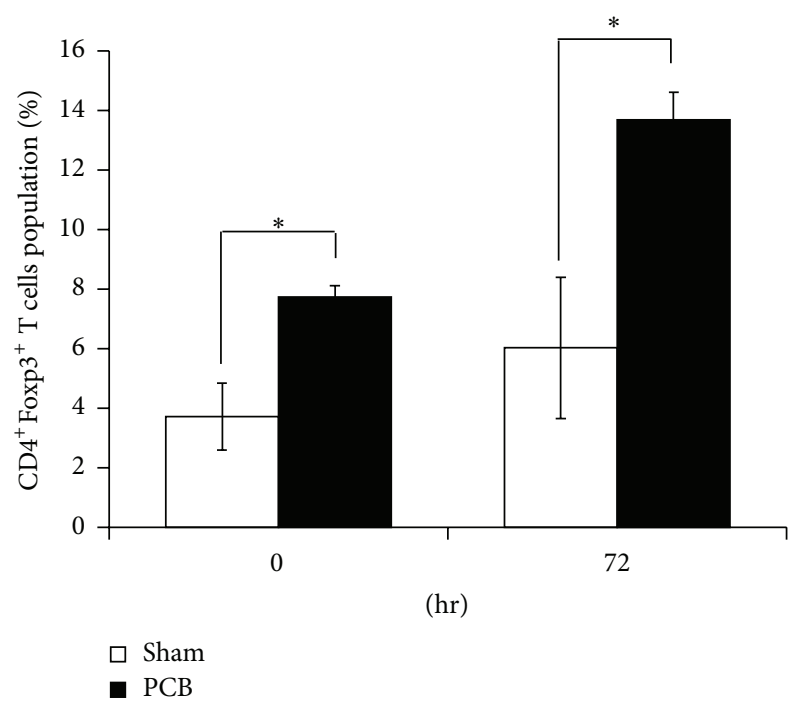

(d)

FIGURE 3: PCB extract suppressed infiltrated immune cell and Th2-related cytokine via Foxp3 regulation in a mouse model of AD. (a) For analyzed immune cells in ear, ear tissues were isolated single cells. The cells were stained with with anti-CD4 (FITC), anti-CD8 (APC/Cy7), anti-CD11c (PE), anti-CD11b (APC), and anti CD45R (PerCP/Cy5.5). These surface molecules of immune cells were measured by flow cytometry. To measure cytokines, the cells isolated from dLNs were restimulated with $100 \mu \mathrm{g} / \mathrm{mL}$ HDM extract and cultured for $72 \mathrm{~h}$. IL4 (b) and IL-10 (c) were detected by ELISA. (d) To evaluate population of CD4 ${ }^{+}$Foxp ${ }^{+} \mathrm{T}$ cells, the cells isolated from dLNs were cultured with PMA $(50 \mathrm{ng} / \mathrm{mL})$ and Ionomycin $(250 \mathrm{ng} / \mathrm{mL})$. After staining with CD4 and Foxp3, the population of CD ${ }^{+}$Foxp $3^{+} \mathrm{T}_{\text {cells }}$ was analyzed by flow cytometry at $0 \mathrm{~h}$ and $72 \mathrm{~h}$. Each value is shown as mean $\pm \mathrm{SD}(n=3) .{ }^{*} P<0.05,{ }^{* *} P<0.01$, and ${ }^{* * *} P<0.001$ compared with sham group. Data were analyzed using ANOVA followed by $F$-protected Fisher's least significant difference test.

the Foxp $3^{+} \mathrm{CD} 4^{+}$Treg population with or without APC (Figure 6(a)). The PCB extract significantly increased the Foxp $3^{+} \mathrm{CD} 4^{+}$Treg population in a dose-dependent manner (Figure 6(b)). We next examined whether PCB-induced Foxp $3^{+} \mathrm{CD} 4^{+}$Tregs could suppress naïve $\mathrm{CD}^{+}{ }^{+} \mathrm{T}$ cell proliferation. CFSE-labeled $\mathrm{CD} 4^{+} \mathrm{CD} 62 \mathrm{~L}^{+}$naïve $\mathrm{T}$ cells were cocultured with $\mathrm{T}$ cells, which had been precultured with PCB extract for 3 days, in the presence or absence of TCR stimulation for 3 days. $\mathrm{CD}^{+} \mathrm{T}$ cell proliferation was then analyzed by measuring the CFSE signal using FACS. $\mathrm{CD}^{+} \mathrm{CD}^{-} \mathrm{L}^{+} \mathrm{T}$ cells cocultured with $\mathrm{PCB}$-treated $\mathrm{CD} 4^{+}$ cells showed significantly reduced proliferation compared with control (59.6 versus 75\%), presumably because of their increased Foxp $3^{+}$Treg population (Figure 6(c)).
To assess the effect of PCB extract on the maintenance of Foxp3 expression in Tregs, we isolated Foxp3-GFP by sorting CD $45.2^{+}$nTregs from the thymus of C57BL/6 mice. The stability of Foxp $3^{+}$Tregs in control group decreased significantly by $63.43 \%$ from $99 \%$ after 3 days. In contrast, the expression of Foxp3 in PCB-treated Tregs remained $74.91 \%$ (Figures 6(d) and 6(e)). These results indicated that PCB possesses activity that might directly generate and stabilize functional Foxp $3^{+} \mathrm{CD} 4^{+}$Tregs.

\subsection{PCB Extract Suppressed Cytokine Production in Effector} $T$ Cells. We investigated whether the increased expression of $\mathrm{CD}^{+} \mathrm{Foxp}^{+}$Tregs affected effector $\mathrm{T}$ cell function. $\mathrm{CD} 4{ }^{+} \mathrm{CD} 62 \mathrm{~L}^{+} \mathrm{T}$ cells were isolated from the spleen and 


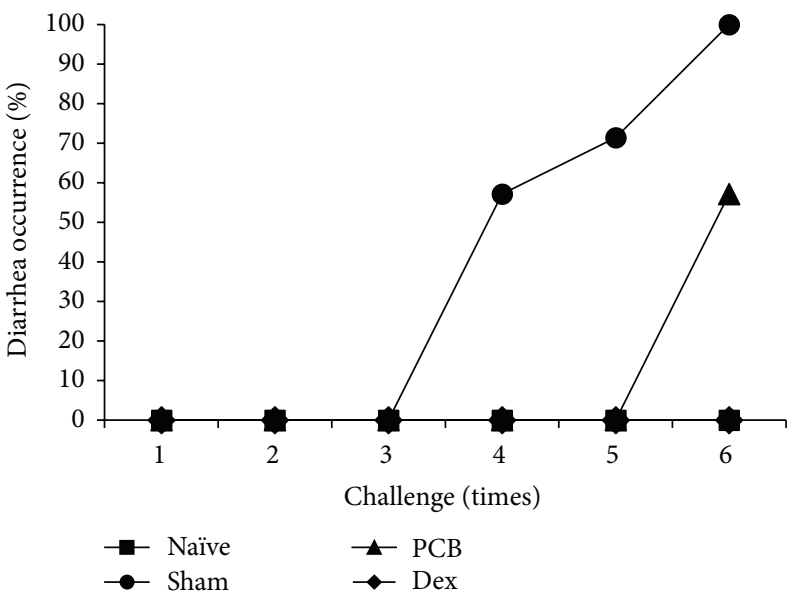

(a)

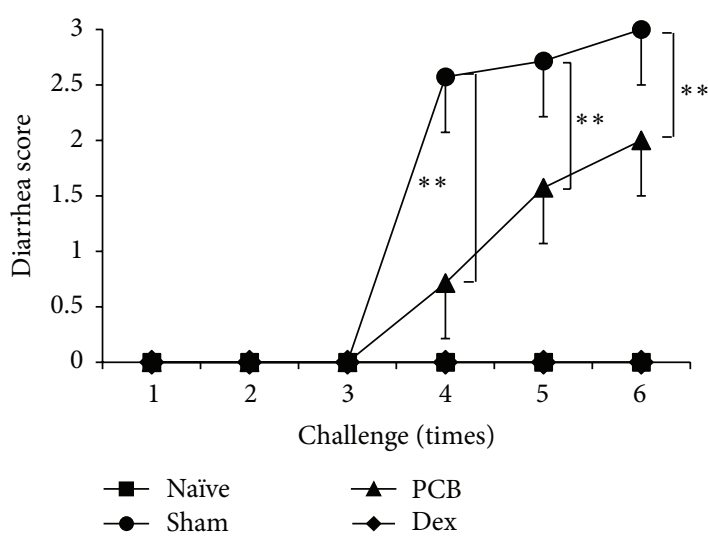

(c)

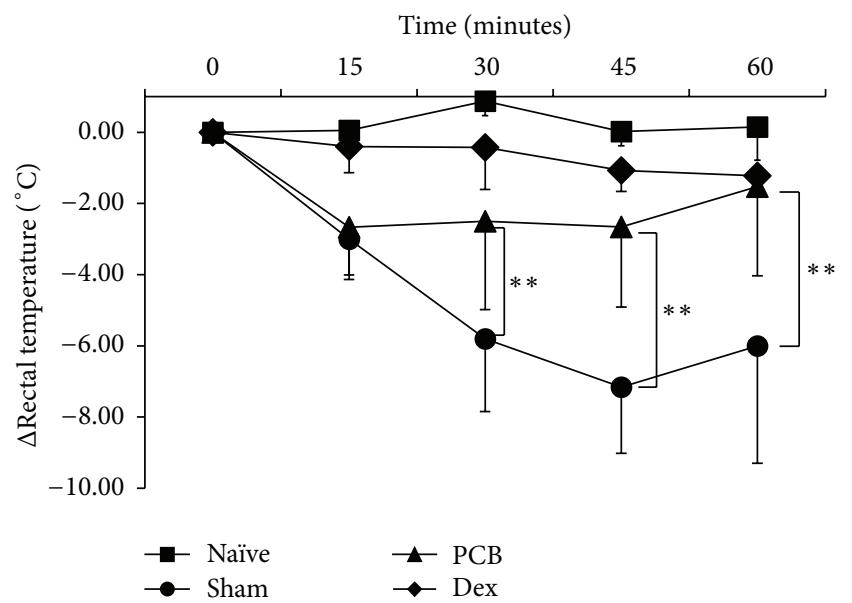

(e)

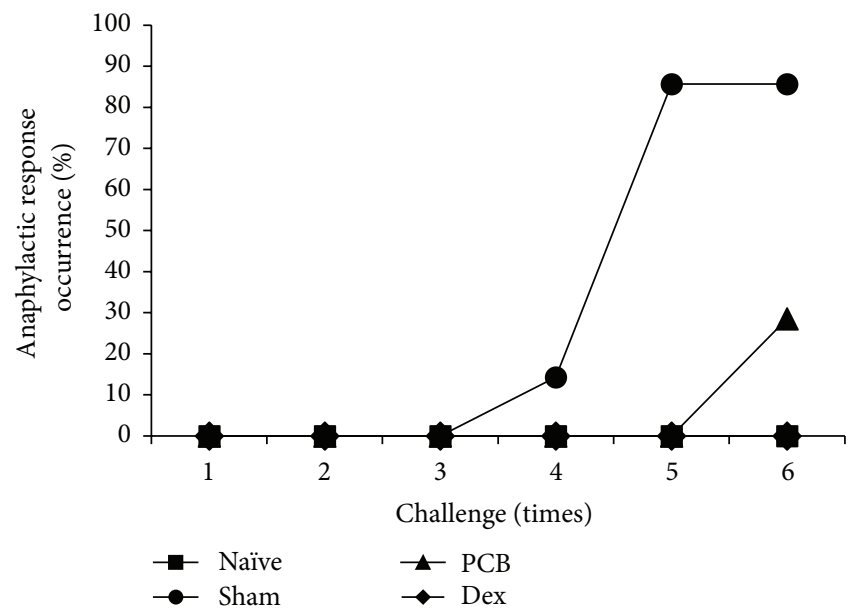

(b)

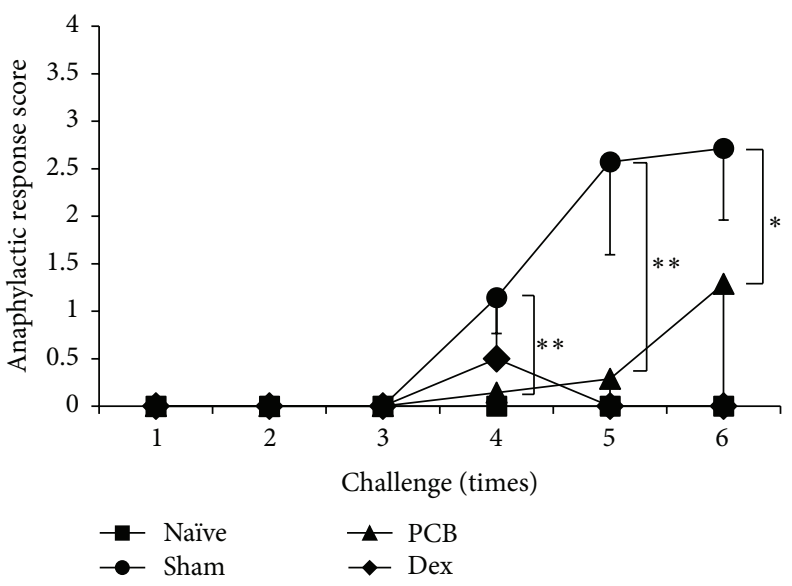

(d)

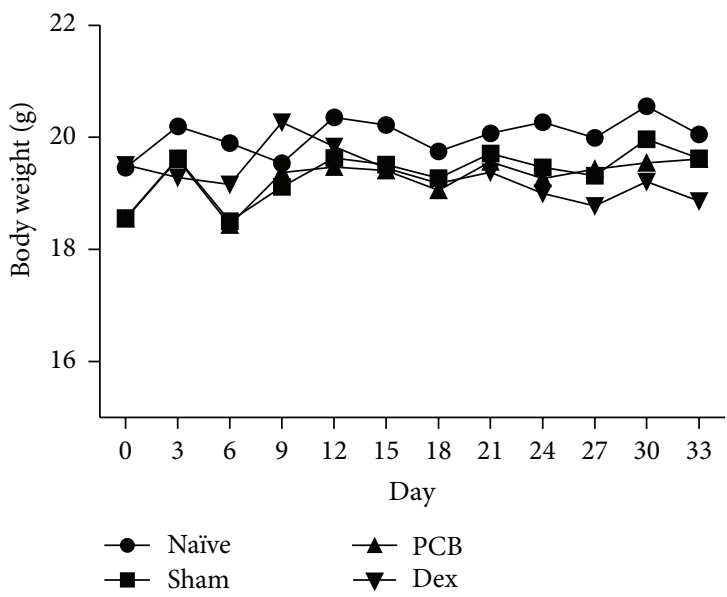

(f)

FIGURE 4: Effect of PCB extract on ovalbumin-induced diarrhea, anaphylactic response, and rectal temperature. OVA-induced food allergic symptoms were evaluated and scored by criteria for diarrhea and the anaphylactic response for $1 \mathrm{~h}$ after challenge with OVA. The diarrhea score (a), diarrhea occurrence (\%, score $\geq 2)(c)$, anaphylactic response score (b), and anaphylactic response occurrence (\%, score $\geq 2)(d)$ were evaluated on all challenges. (e) Rectal temperature was measured every $15 \mathrm{~min}$ for $1 \mathrm{~h}$ after the sixth OVA challenge. (f) Body weight during experiments. Data are presented as mean \pm SD. Bars represent significant differences from the sham group at ${ }^{*} P<0.05$ and ${ }^{* *} P<0.01$ versus sham. Data were analyzed using one-way repeated measures of ANOVA followed by Dunnett's post hoc test. 


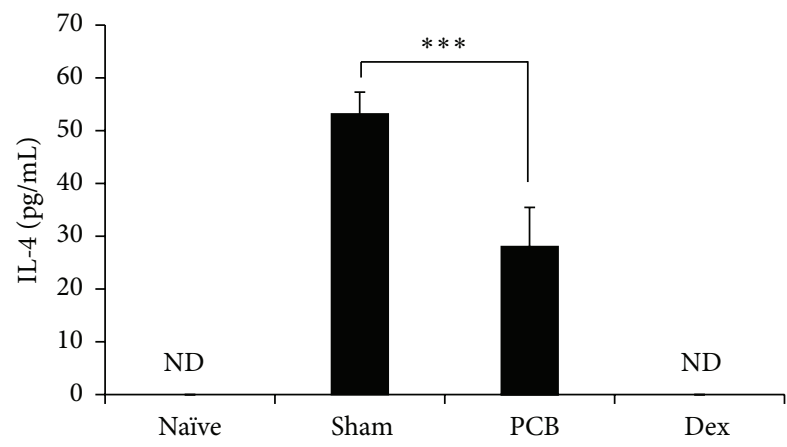

(a)

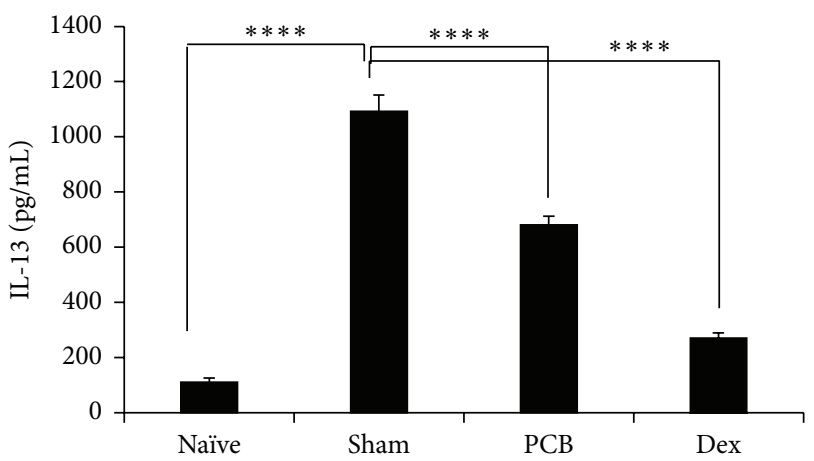

(c)

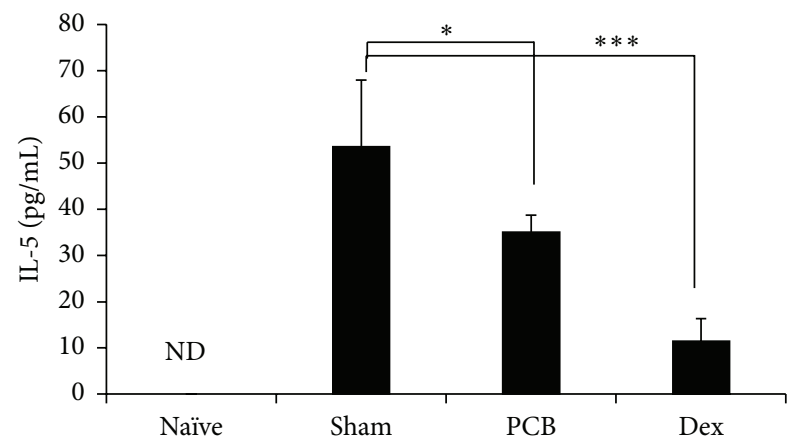

(b)

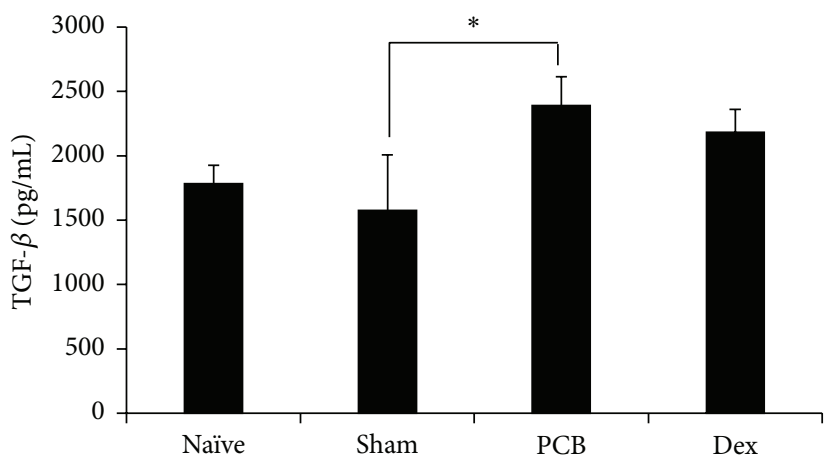

(d)

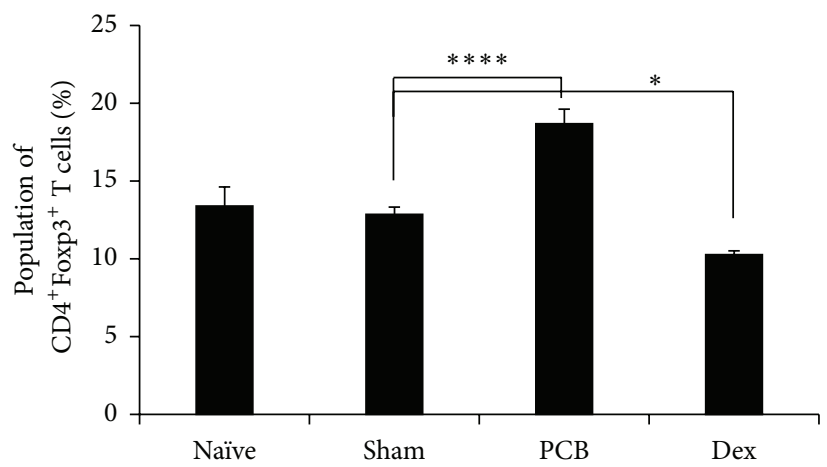

(e)

FIGURE 5: Immunomodulatory effects of PCB extract on cytokine expression patterns in mesenteric lymph nodes of food allergic mouse. Mice were sacrificed by cervical dislocation on day 35 , and mLNs were isolated. mLNs were cultured in RPMI medium containing $10 \%$ fetal bovine serum for $72 \mathrm{~h}$. Cytokines secreted from mLNs were quantified by ELISA. Interleukin- (IL-) 4 (a), IL-5 (b), IL-13 (c), and TGF- $\beta$ (d) were measured. (e) The expression of Foxp3 in gated CD4 $4^{+}$cells was analyzed using flow cytometry. Data are presented as the mean of the percentage of Foxp $3^{+} \mathrm{CD}^{+} \mathrm{T}$ cells from three independent experiments and as mean $\pm \mathrm{SD}$. Data were analyzed using one-way repeated measure ANOVA followed by Dunnett's post hoc test. Bars represent significant differences from the sham group at ${ }^{*} P<0.05,{ }^{* * *} P<0.001$, and ${ }^{* * * *} P<0.0001$.

mLNs of $B A L B / c$ mice and were treated with anti-CD3 and anti-CD28 antibodies for $72 \mathrm{~h}$. The levels of Th1 (IFN- $\gamma$ ), Th2 (IL-4), Th17 (IL-17), and Treg (TGF- $\beta$ ) cytokines in culture supernatants were then measured using ELISA. IFN- $\gamma$, IL-4, and IL-17 levels decreased in the PCB-treated compared with the TCR stimulated group, but TGF- $\beta$ levels were increased in PCB-treated cells (Figures 7(a) $-7(\mathrm{~d})$ ).

To further confirm the effect of PCB extract on Tregrelated gene expression, $\mathrm{CD} 4^{+} \mathrm{CD}_{2} \mathrm{~L}^{+} \mathrm{T}$ cells isolated from mouse spleens and mLNs were treated with anti-CD3 and anti-CD28 antibodies for $24 \mathrm{hr}$. The mRNA expression of
Treg-associated genes was then measured (Figure 7(e)). PCBtreated inducible Foxp $3^{+} \mathrm{CD}^{+} \mathrm{T}$ cells upregulated CTLA-4, GranB, and TGF- $\beta$ expression compared with control. The expression of $A h R$ also increased dramatically after treatment with PCB extract. This suggests that PCB extract could exert immunosuppressive effects on effector $\mathrm{T}$ cells by inducing functional Foxp $3^{+} \mathrm{CD} 4^{+}$Tregs.

3.5. PCB Extract Directly Affects Naïve $C D 4^{+} T$ Cells to Induce Tregs via AhR Activation. AhR activation suppresses Th2type cells and antibody responses and induces Foxp $3^{+}$Tregs 


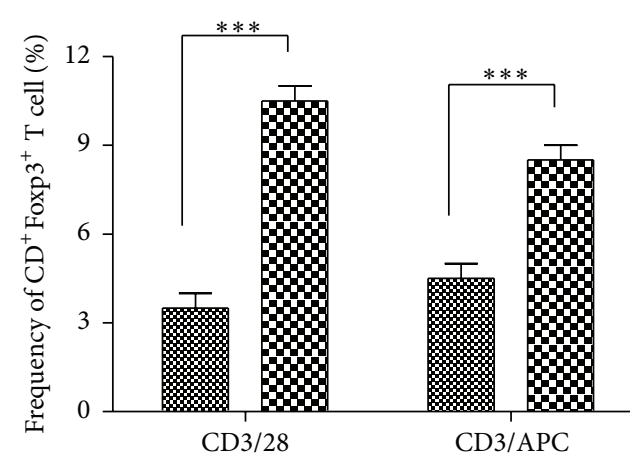

88. Sham

푸르 PCB $10 \mu \mathrm{g} / \mathrm{mL}$

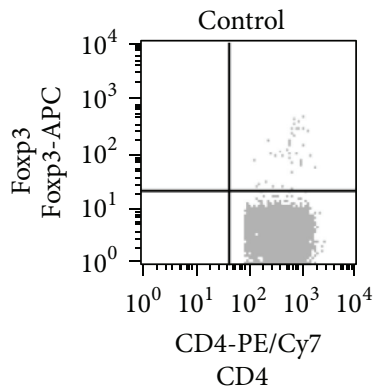

$\mathrm{CD} 4$

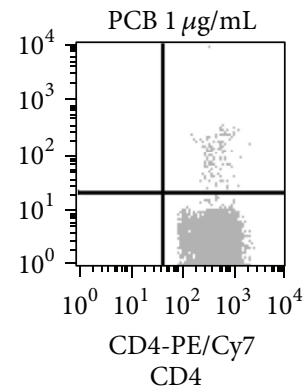

(b)

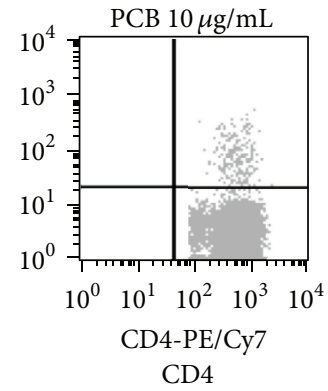

CD4
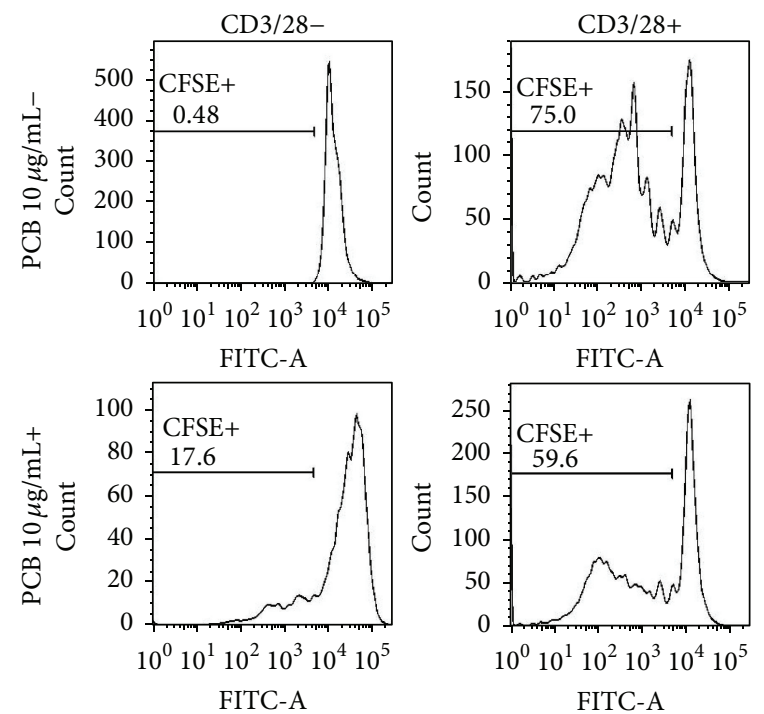

(c)

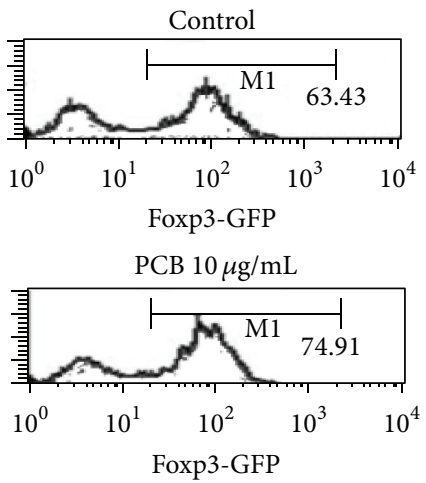

(d)

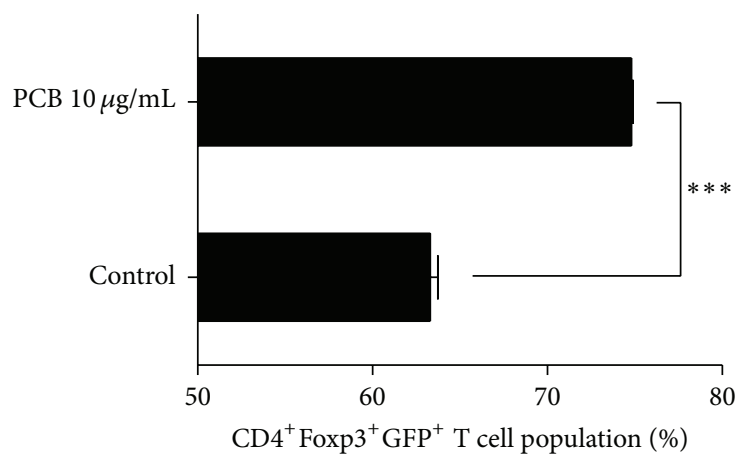

(e)

Figure 6: PCB extract affects the generation and functional Foxp $3^{+}$T regulatory cells and stabilizes the Foxp 3 expression of regulatory T cells. (a) and (b) $\mathrm{CD}^{+} \mathrm{CD} 2 \mathrm{~L}^{+}$naive T cell from splenocytes and $\mathrm{mLN}$ cells from BALB/c mice were cultured with $10 \mu \mathrm{g} / \mathrm{mL}$ plate-bound antiCD3 monoclonal antibody and $2 \mu \mathrm{g} / \mathrm{mL}$ soluble anti-CD28 mAb, or with $10 \mu \mathrm{g} / \mathrm{mL}$ plate-bound anti-CD3 mAb and APCs, in the presence of $0-10 \mu \mathrm{g} / \mathrm{mL}$ PCB. After three days, the expression of Foxp3 in gated CD4 ${ }^{+}$cells was analyzed using flow cytometry. A plot from one representative experiment shows the frequency of Foxp $3^{+} \mathrm{CD} 4^{+} \mathrm{T}$ cells. (c) $\mathrm{CD} 4^{+} \mathrm{T}$ cells from each group were cocultured with $\mathrm{CD} 4^{+} \mathrm{CD} 62 \mathrm{~L}^{+}$ naïve T cells labeled with CFSE $(5 \mu \mathrm{M}), 10 \mu \mathrm{g} / \mathrm{mL}$ plate-bound anti-CD3 $\mathrm{mAb}$, and $2 \mu \mathrm{g} / \mathrm{mL}$ soluble anti-CD28 $\mathrm{mAb}$. The CFSE ${ }^{+}$population was then analyzed using FACS. (d) Ag-specific GFP ${ }^{+}$nTregs were sorted from the OT-II transgenic Foxp3-GFP knock-in mice and transferred to normal recipients. Five days after immunization, the transferred CD $45.2^{+}$cells were analyzed for Foxp3 expression using flow cytometry. (e) The numbers in M1 represent the percentage of Foxp $3^{+}$cells. The plot presents the mean percentage of CD $45.2^{+}$Foxp $3^{+} \mathrm{T}$ cells of three independent experiments. Data are presented as the mean \pm SD of triplicate determinations and were analyzed using unpaired $t$-test. ${ }^{* * *} P<$ 0.001 versus control. 


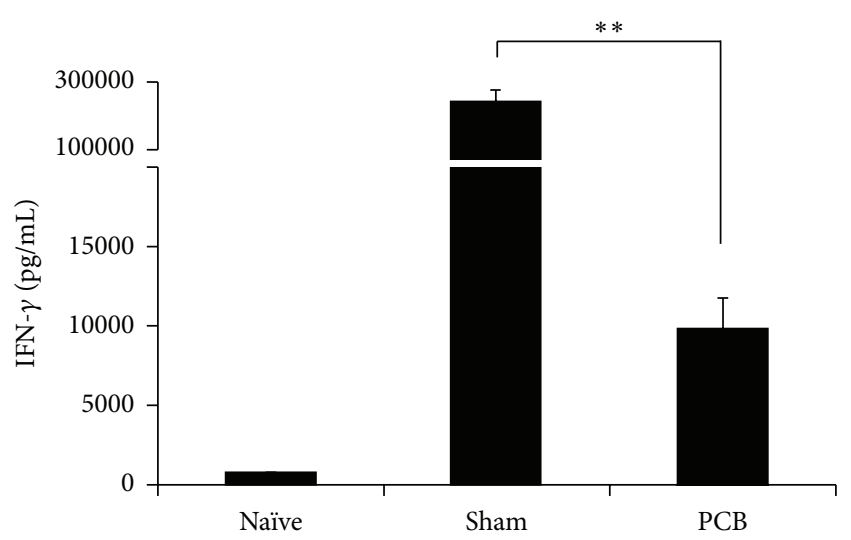

(a)

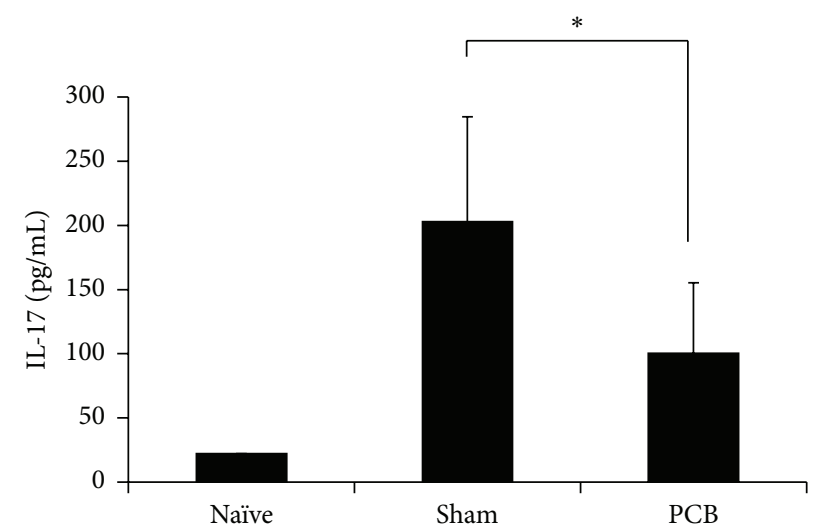

(c)

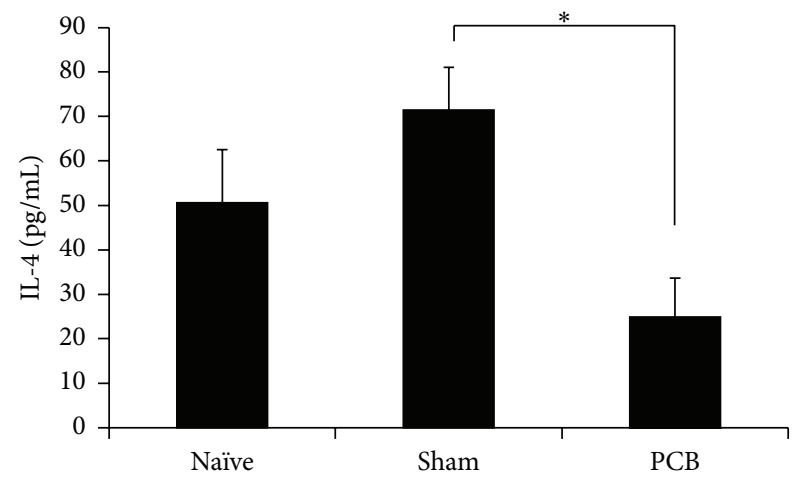

(b)

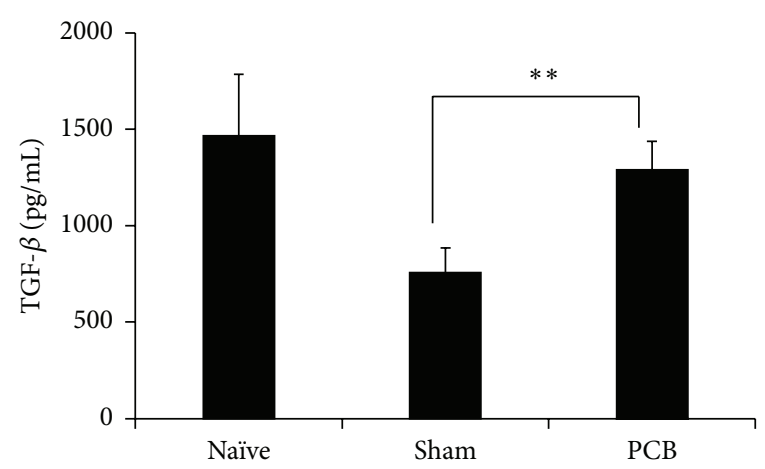

(d)

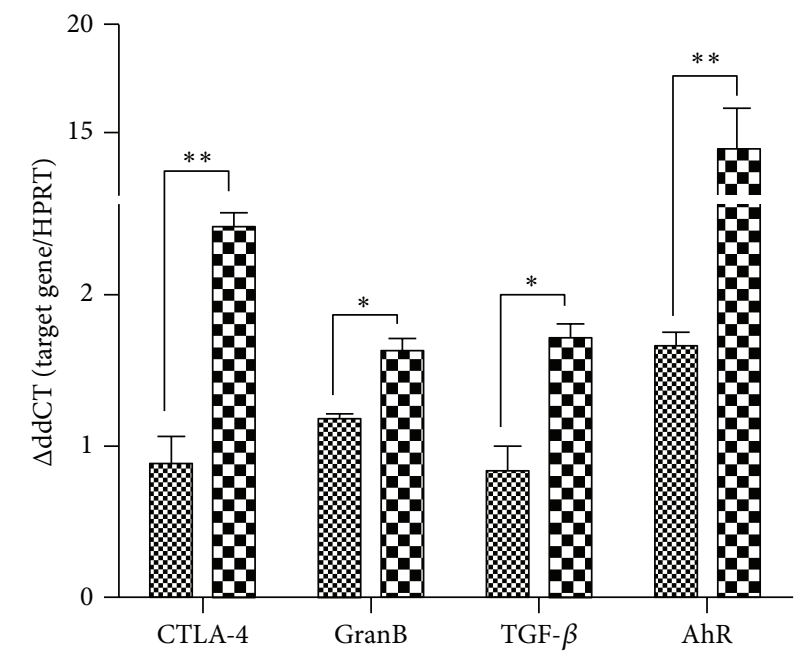

\&8 Sham

EDC PCB $10 \mu \mathrm{g} / \mathrm{mL}$

(e)

FIgURE 7: PCB extract contributed to an expanded population of inducible T regulatory cells. $\mathrm{CD}_{4}^{+} \mathrm{CD}_{2} \mathrm{~L}^{+}$naïve $\mathrm{T}$ cells from splenocytes and mLN cells from BALB/c mice were cultured with $10 \mu \mathrm{g} / \mathrm{mL}$ plate-bound anti-CD3 mAb and $2 \mu \mathrm{g} / \mathrm{mL}$ soluble anti-CD28 mAb in the presence of $0-10 \mu \mathrm{g} / \mathrm{mL}$ PCB. After three days, the levels of IFN- $\gamma$ (a), IL-4 (b), IL-17 (c), and TGF- $\beta$ (d) in the culture supernatants were measured using ELISA. Data are presented as the mean \pm SD of triplicate determinations and were analyzed using ANOVA followed by $F-$ protected Fisher's least significant difference test. ${ }^{*} P<0.05$; ${ }^{* *} P<0.01$ versus OVA control. (e) The expression of Treg-associated molecules was compared between the sham and experimental groups. GranB: Granzyme B. Data are presented as the mean \pm standard deviation (SD) of triplicate determinations and were analyzed using unpaired $t$-test. ${ }^{*} P<0.05$ and ${ }^{* *} P<0.01$ versus OVA control. 


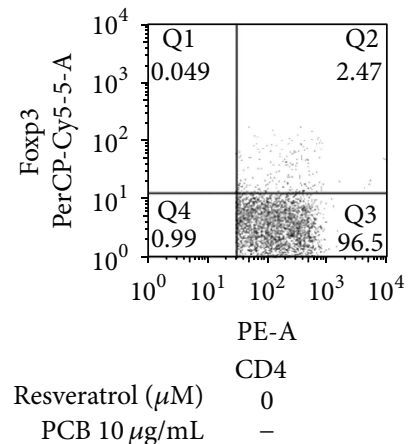

PCB $10 \mu \mathrm{g} / \mathrm{mL}$
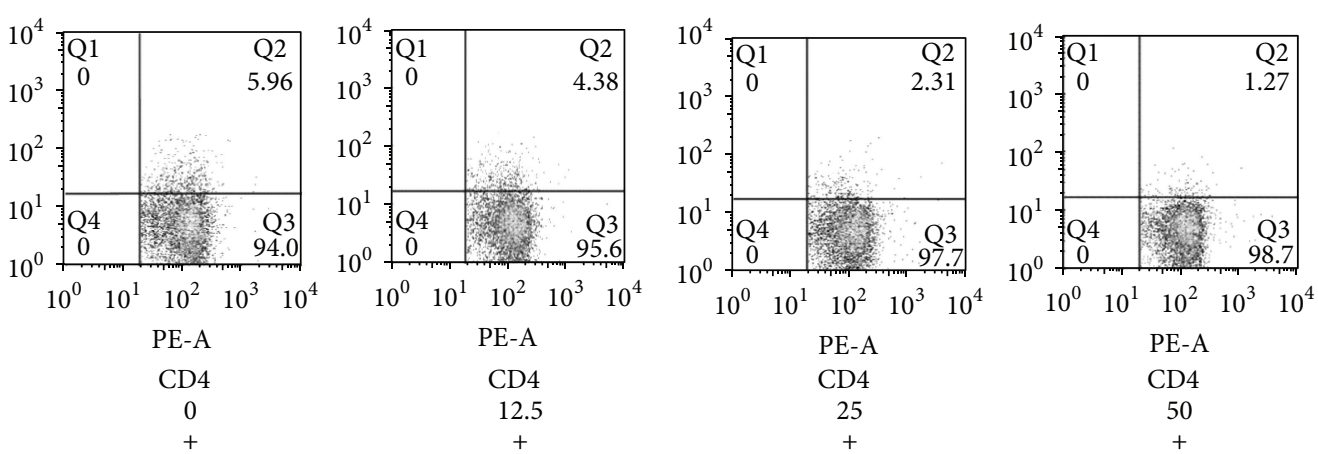

(a)

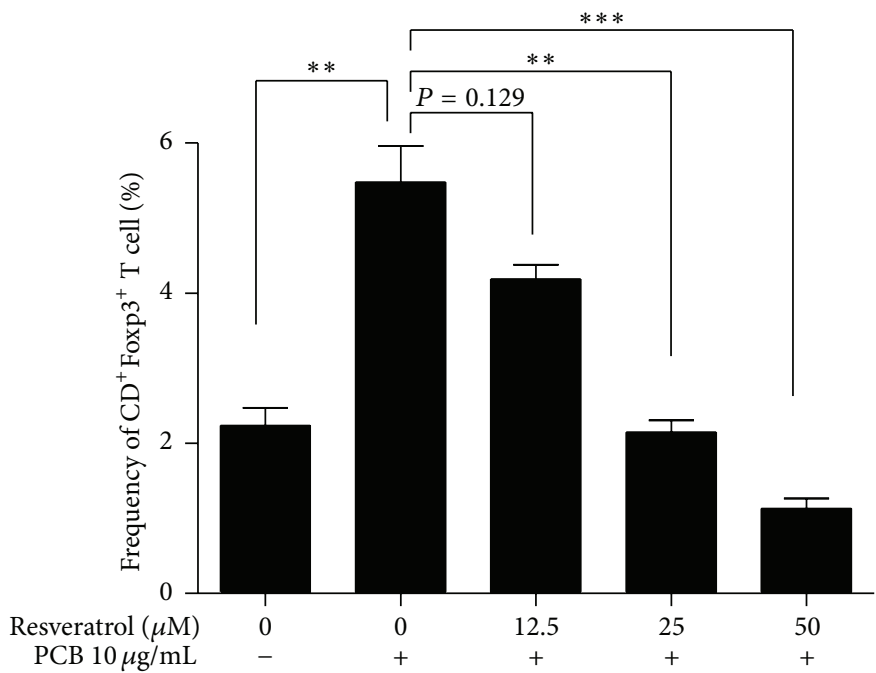

(b)

FIGURE 8: PCB extract induced the generation of inducible T regulatory cells via the aryl hydrocarbon receptor. (a) $\mathrm{CD}^{+} \mathrm{CD} 62 \mathrm{~L}^{+}$naïve $\mathrm{T}$ cell from splenocytes and $\mathrm{mLN}$ cells from BALB/c mice were stimulated with anti-CD3 and anti-CD28 antibodies in the presence of $10 \mu \mathrm{g} / \mathrm{mL}$ $\mathrm{PCB}$ and the AhR antagonist resveratrol $(12.5,25$, and $50 \mu \mathrm{M})$ for $72 \mathrm{~h}$. Foxp $3^{+} \mathrm{CD} 4^{+} \mathrm{T}$ cell populations were then quantified using flow cytometry. (b) The plots show the mean population of Foxp $3^{+} \mathrm{CD} 4^{+} \mathrm{T}$ cells from three independent experiments. Data are presented as the mean \pm standard deviation (SD) of triplicate determinations and were analyzed using one-way repeated measures of ANOVA followed by Dunnett's post hoc test. ${ }^{* *} P<0.01$ and ${ }^{* * *} P<0.001$ versus control.

$[16,31]$. We measured whether the PCB-induced expression of Foxp3 in naïve $\mathrm{CD}^{+} \mathrm{T}$ cells required AhR activation. Naïve $\mathrm{CD} 4^{+} \mathrm{CD} 62 \mathrm{~L}^{+} \mathrm{T}$ cells were cultured with resveratrol, an AhR antagonist [32], TCR stimulation, and PCB extract. Resveratrol decreased the PCB-induced Foxp $3^{+} \mathrm{CD}^{+}{ }^{+}$Treg population in a dose-dependent manner (Figure 8). This suggests that the induction of functional Foxp $3^{+} \mathrm{CD} 4^{+}$Tregs by $\mathrm{PCB}$ extract required AhR activation.

\section{Discussion}

In this study, we focused on the antiallergic role of Tregs, which were induced by PCB extract, and whether these Tregs were associated with immune tolerance in $\mathrm{AD}$ and FA. This study demonstrated that the oral administration of PCB extract suppressed allergic symptoms without side effects and induced Foxp $3^{+} \mathrm{CD} 4^{+}$Tregs. Furthermore, our data showed that PCB extract promoted the generation and maintenance of functional Foxp $3^{+} \mathrm{CD} 4^{+}$Tregs in an AhRdependent manner.

We confirmed that PCB extract effectively suppressed IL-4 production, which is the main Th2-mediated cytokine, and is a potent oral immune regulator of in HDM-induced experimental $\mathrm{AD}$. We suggest that the underlying mechanism is induction of Tregs because the oral administration of PCB extract induced both CD $4^{+}$Foxp $3^{+} \mathrm{T}$ cells and IL-10 production. IL-10-producing $\mathrm{CD}^{+}{ }^{+} \mathrm{T}$ cells are well known as type $1 \mathrm{~T}$ regulatory $(\mathrm{Tr} 1)$ cells, and an increase in their population could ameliorate $\mathrm{AD}[33,34]$. However, it was known that other immune cells such as macrophages, B cells, and dendritic cells could also promote IL-10 production with Treg or Tr1. IL-10-producing cells called type 2 macrophages, Breg, and tolerogenic DC also could suppress Th2-related immune responses in allergic disorders such as $\mathrm{AD}$ [3537]. The main population of IL-10-producing cells in HDMinduced $\mathrm{AD}$ may be revealed through further studies. 
Increase in Foxp $3^{+} \mathrm{CD}^{+}$Tregs has been linked to inhibition of FAs initiated by Th2-related cytokines such as IL-4, IL-5, and IL-13 [38-40]. In this study, PCB extract administration significantly promoted oral tolerance via the generation of Foxp $3^{+}$Tregs and suppressed OVA-induced Th2-dominant immune responses in FA. Previous studies have demonstrated that the induction of Tregs could alleviate symptoms of food allergy, despite the relatively small proportion in immune cells [41]. Tregs inhibit the uncontrolled activation and expansion of T cells [15]. They directly suppress the activation and expansion of allergen-specific Th2 cells during allergic reactions [15, 42]. Many studies have reported the role played by TGF- $\beta$ in mechanisms regulating the induction of tolerance at the gastrointestinal tract $[43,44]$. TGF- $\beta$ can efficiently convert naïve $\mathrm{T}$ cells into Tregs. TGF- $\beta$ promote the nuclear translocalization of phosphorylated Smad3 which contributes to Foxp3 initiation [45], a Treg-specific transcription factor. Our data also showed that oral administration of PCB extract increased TGF- $\beta$ production and Foxp 3 expression in $\mathrm{mLN}$ of the OVAinduced pathogenic mice. Moreover, PCB extracts stabilized the expression of inducible Foxp3. We therefore suppose that oral tolerance by administration of PCB may improve allergic disorders such as FA via the stable induction of TGF- $\beta$ dominated Foxp3 expression.

AhR plays an important role in $\mathrm{T}$ cell differentiation. Curcumin, a dietary AhR compound found in turmeric, attenuates inflammation in asthma and systemic lupus erythematosus by regulating the induction of Tregs [19, 46, 47]. In addition, I3C and indirubin increase the number of $\mathrm{CD} 4^{+} \mathrm{CD} 25^{+}$Tregs and suppress chronic inflammatory diseases and/or autoimmunity in vivo [20]. In this study, PCB extract significantly increased AhR expression. Moreover, no increase in Foxp3 expression was found in the presence of the AhR antagonist resveratrol. This suggests that the immunosuppressive effects of PCB extract are mediated via $A h R$ and that AhR expression and activation are essential for PCB-mediated Foxp3 ${ }^{+}$Treg generation. Some chemical constituents of PCB have been reported to be AhR agonists. For example, ergosterol regulated human CYP enzymes via AhR activation $[48,49]$ and hydrophobic triterpenes have a high affinity for AhR and induce its activation [26, 27, 50]. In this study, we found that $\mathrm{CD}^{+}{ }^{+} \mathrm{Foxp}^{+}$Tregs were efficiently generated by the hexane fraction of $\mathrm{PCB}$ containing ergosterol and triterpenes (data not shown). Consequently, it could be speculated that the ergosterol and triterpenes of PCB can induce Tregs. However, there remains a need to explore the putative compound(s) responsible for Foxp 3 expression in naïve $\mathrm{CD} 4^{+} \mathrm{CD} 62 \mathrm{~L}^{+} \mathrm{T}$ cells in the hexane fraction of $\mathrm{PCB}$.

In conclusion, $\mathrm{PCB}$ extracts exerted potent immunosuppressive effects by potentiating the generation and maintenance of functional Foxp $3^{+} \mathrm{CD} 4^{+}$Tregs in an AhR-dependent manner. Moreover, PCB-induced Foxp $3^{+} \mathrm{CD} 4^{+}$Tregs effectively suppressed the symptoms of $\mathrm{AD}$ and FAs. Therefore, PCB extracts have potential as orally active immune suppressors for the treatment of hypersensitive immune responses disorders such as $\mathrm{AD}$ and FA.

\section{Abbreviations}

$\begin{array}{ll}\text { AD: } & \text { Atopic dermatitis } \\ \text { APCs: } & \text { Antigen-presenting cells } \\ \text { Dex: } & \text { Dexamethasone } \\ \text { DfE: } & \text { Dermatophagoides farinae extracts } \\ \text { dLN: } & \text { Draining lymph node } \\ \text { DNCB: } & \text { Dinitrochlorobenzene } \\ \text { Foxp3: } & \text { Forkhead box P3 } \\ \text { H\&E: } & \text { Hematoxylin and eosin } \\ \text { IFN: } & \text { Interferon } \\ \text { Ig: } & \text { Immunoglobulin } \\ \text { IL: } & \text { Interleukin } \\ \text { iTreg: } & \text { Inducible Treg } \\ \text { mLN: } & \text { Mesenteric lymph node } \\ \text { OVA: } & \text { Ovalbumin } \\ \text { PCB: } & \text { Poria cocos } \\ \text { ROR } \gamma \text { T: } & \text { Retinoic acid-related orphan receptor } \gamma \mathrm{T} \\ \text { TCR: } & \text { T cell receptor } \\ \text { Teff cells: } & \text { Effector T cells } \\ \text { TGF- } \beta: & \text { Transforming growth factor- } \beta \\ \text { Th: } & \text { T-helper } \\ \text { Thl7 cells: } & \text { IL-17-producing Th cells } \\ \text { Tregs: } & \text { Regulatory T cells. } \\ \end{array}$

\section{Competing Interests}

The authors have declared no conflict of interests.

\section{Authors' Contributions}

Min-Jung Bae and Hye-Jeong See contributed equally to this work.

\section{Acknowledgments}

This study was supported by research grants (E0121304-05) from the Korea Food Research Institute (KFRI).

\section{References}

[1] C. Venter, B. Pereira, K. Voigt et al., "Prevalence and cumulative incidence of food hypersensitivity in the first 3 years of life," Allergy, vol. 63, no. 3, pp. 354-359, 2008.

[2] D. Y. M. Leung, M. Boguniewicz, M. D. Howell, I. Nomura, and Q. A. Hamid, "New insights into atopic dermatitis," Journal of Clinical Investigation, vol. 113, no. 5, pp. 651-657, 2004.

[3] D. Y. Leung and T. Bieber, "Atopic dermatitis," The Lancet, vol. 361, no. 9352, pp. 151-160, 2003.

[4] J. M. Spergel, "From atopic dermatitis to asthma: the atopic march," Annals of Allergy, Asthma and Immunology, vol. 105, no. 2, pp. 99-106, 2010.

[5] N. Novak, "New insights into the mechanism and management of allergic diseases: atopic dermatitis," Allergy, vol. 64, no. 2, pp. 265-275, 2009.

[6] S. Bonness and T. Bieber, "Molecular basis of atopic dermatitis," Current Opinion in Allergy and Clinical Immunology, vol. 7, no. 5, pp. 382-386, 2007. 
[7] S. H. Sicherer and H. A. Sampson, "Food allergy," The Journal of Allergy and Clinical Immunology, vol. 125, no. 2, supplement 2, pp. S116-S125, 2010.

[8] M. Ben-Shoshan and A. E. Clarke, "Anaphylaxis: past, present and future," Allergy, vol. 66, no. 1, pp. 1-14, 2011.

[9] J. J. Koplin, P. E. Martin, and K. J. Allen, "An update on epidemiology of anaphylaxis in children and adults," Current Opinion in Allergy and Clinical Immunology, vol. 11, no. 5, pp. 492-496, 2011.

[10] T. M. Brusko, A. L. Putnam, and J. A. Bluestone, "Human regulatory T cells: role in autoimmune disease and therapeutic opportunities," Immunological Reviews, vol. 223, no. 1, pp. 371390, 2008.

[11] C. Dejaco, C. Duftner, B. Grubeck-Loebenstein, and M. Schirmer, "Imbalance of regulatory T cells in human autoimmune diseases," Immunology, vol. 117, no. 3, pp. 289-300, 2006.

[12] S. A. Long and J. H. Buckner, " $\mathrm{CD} 4{ }^{+} \mathrm{FOXP}^{+}$T regulatory cells in human autoimmunity: more than a numbers game," Journal of Immunology, vol. 187, no. 5, pp. 2061-2066, 2011.

[13] M. Chehade and L. Mayer, "Oral tolerance and its relation to food hypersensitivities," The Journal of Allergy and Clinical Immunology, vol. 115, no. 1, pp. 3-12, 2005.

[14] L. Gabryšová, J. R. Christensen, X. Wu, A. Kissenpfennig, B. Malissen, and A. O'Garra, "Integrated T-cell receptor and costimulatory signals determine TGF- $\beta$-dependent differentiation and maintenance of Foxp ${ }^{3+}$ regulatory T cells," European Journal of Immunology, vol. 41, no. 5, pp. 1242-1248, 2011.

[15] S. Hori, T. Nomura, and S. Sakaguchi, "Control of regulatory T cell development by the transcription factor Foxp3," Science, vol. 299, no. 5609, pp. 1057-1061, 2003.

[16] F. J. Quintana, A. S. Basso, A. H. Iglesias et al., "Control of $\mathrm{T}_{\text {reg }}$ and $\mathrm{T}_{H} 17$ cell differentiation by the aryl hydrocarbon receptor," Nature, vol. 453, no. 7191, pp. 65-71, 2008.

[17] J. Adachi, Y. Mori, S. Matsui et al., "Indirubin and indigo are potent aryl hydrocarbon receptor ligands present in human urine," The Journal of Biological Chemistry, vol. 276, no. 34, pp. 31475-31478, 2001.

[18] M. Ociepa-Zawal, B. Rubiś, M. Łaciński, and W. H. Trzeciak, "The effect of indole-3-carbinol on the expression of CYP1A1, CYP1B1 and AhR genes and proliferation of MCF-7 cells," Acta Biochimica Polonica, vol. 54, no. 1, pp. 113-117, 2007.

[19] A. Goergens, M. Frericks, and C. Esser, "The arylhydrocarbon receptor is only marginally involved in the antileukemic effects of its ligand curcumin," Anticancer Research, vol. 29, no. 11, pp. 4657-4664, 2009.

[20] J. M. Benson and D. M. Shepherd, "Dietary ligands of the aryl hydrocarbon receptor induce anti-inflammatory and immunoregulatory effects on murine dendritic cells," Toxicological Sciences, vol. 124, no. 2, pp. 327-338, 2011.

[21] A. L. Mellor, P. Chandler, B. Baban et al., "Specific subsets of murine dendritic cells acquire potent $\mathrm{T}$ cell regulatory functions following CTLA4-mediated induction of indoleamine 2,3 dioxygenase," International Immunology, vol. 16, no. 10, pp. 1391-1401, 2004.

[22] J.-L. Ríos, "Chemical constituents and pharmacological properties of poria cocos," Planta Medica, vol. 77, no. 7, pp. 681-691, 2011.

[23] S. M. Fuchs, C. Heinemann, S. Schliemann-Willers, H. Härtl, J. W. Fluhr, and P. Elsner, "Assessment of anti-inflammatory activity of Poria cocos in sodium lauryl sulphate-induced irritant contact dermatitis," Skin Research and Technology, vol. 12, no. 4, pp. 223-227, 2006.
[24] H.-H. Chang, C.-H. Yeh, and F. Sheu, "A novel immunomodulatory protein from Poria cocos induces Toll-like receptor 4dependent activation within mouse peritoneal macrophages," Journal of Agricultural and Food Chemistry, vol. 57, no. 14, pp. 6129-6139, 2009.

[25] Y.-T. Lu, Y.-C. Kuan, H.-H. Chang, and F. Sheu, "Molecular cloning of a Poria cocos protein that activates Th1 immune response and allays Th2 cytokine and IgE production in a murine atopic dermatitis model," Journal of Agricultural and Food Chemistry, vol. 62, no. 13, pp. 2861-2871, 2014.

[26] T. Akihisa, Y. Nakamura, H. Tokuda et al., "Triterpene acids from Poria cocos and their anti-tumor-promoting effects," Journal of Natural Products, vol. 70, no. 6, pp. 948-953, 2007.

[27] S. Ohno, "Roles of Kampo medicine in treating rheumatic diseases," Journal of Traditional Medicines, vol. 24, no. 3, pp. 7380, 2007.

[28] I.-K. Kim, B.-S. Kim, C.-H. Koh et al., "Glucocorticoid-induced tumor necrosis factor receptor-related protein co-stimulation facilitates tumor regression by inducing IL-9-producing helper T cells," Nature Medicine, vol. 21, no. 9, pp. 1010-1017, 2015.

[29] H.-K. Kwon, C.-G. Lee, J.-S. So et al., "Generation of regulatory dendritic cells and $\mathrm{CD} 4^{+} \mathrm{Foxp}^{+} \mathrm{T}$ cells by probiotics administration suppresses immune disorders," Proceedings of the National Academy of Sciences of the United States of America, vol. 107, no. 5, pp. 2159-2164, 2010.

[30] H. S. Shin, M.-J. Bae, S. Y. Jung, and D.-H. Shon, "Preventive effects of skullcap (Scutellaria baicalensis) extract in a mouse model of food allergy," Journal of Ethnopharmacology, vol. 153, no. 3, pp. 667-673, 2014.

[31] V. J. Schulz, J. J. Smit, M. Bol-Schoenmakers, M. B. M. van Duursen, M. van den Berg, and R. H. H. Pieters, "Activation of the aryl hydrocarbon receptor reduces the number of precursor and effector T cells, but preserves thymic $\mathrm{CD} 4^{+} \mathrm{CD} 25^{+} \mathrm{Foxp}^{+}$ regulatory T cells," Toxicology Letters, vol. 215, no. 2, pp. 100109, 2012.

[32] H. P. Ciolino, P. J. Daschner, and G. C. Yeh, "Resveratrol inhibits transcription of CYP1A1 in vitro by preventing activation of the aryl hydrocarbon receptor," Cancer Research, vol. 58, no. 24, pp. 5707-5712, 1998.

[33] M. K. Levings, R. Bacchetta, U. Schulz, and M. G. Roncarolo, "The role of IL-10 and TGF-beta in the differentiation and effector function of T regulatory cells," International archives of allergy and immunology, vol. 129, no. 4, pp. 263-276, 2002.

[34] N. Fyhrquist, S. Lehtimäki, K. Lahl et al., "Foxp3 + cells control Th2 responses in a murine model of atopic dermatitis," Journal of Investigative Dermatology, vol. 132, no. 6, pp. 1672-1680, 2012.

[35] K. A. Haitz and N. Anandasabapathy, "Docosahexaenoic acid alleviates atopic dermatitis in mice by generating $\mathrm{T}$ regulatory cells and $\mathrm{m} 2$ macrophages," The Journal of Investigative Dermatology, vol. 135, no. 6, pp. 1472-1474, 2015.

[36] J. Li, C. Shen, Y. Liu et al., "Impaired Function of $\mathrm{CD}^{+} \mathrm{CD} 19^{+} \mathrm{CD} 1 \mathrm{~d}^{\text {hi }} \mathrm{B} 10$ cells on IgE secretion in an atopic dermatitis-like mouse model," PLoS ONE, vol. 10, no. 8, Article ID e0132173, 2015.

[37] T. Volz, Y. Skabytska, E. Guenova et al., "Nonpathogenic bacteria alleviating atopic dermatitis inflammation induce IL10-producing dendritic cells and regulatory Tr1 cells," Journal of Investigative Dermatology, vol. 134, no. 1, pp. 96-104, 2014.

[38] C. M. Cabrera and J. M. Urra, "Food allergy and the oral immunotherapy approach," Archivum Immunologiae et Therapiae Experimentalis, vol. 63, no. 1, pp. 31-39, 2015. 
[39] S. Cao, T. J. Feehley, and C. R. Nagler, "The role of commensal bacteria in the regulation of sensitization to food allergens," FEBS Letters, vol. 588, no. 22, pp. 4258-4266, 2014.

[40] A. Syed, M. A. Garcia, S.-C. Lyu et al., "Peanut oral immunotherapy results in increased antigen-induced regulatory T-cell function and hypomethylation of forkhead box protein 3 (FOXP3)," The Journal of Allergy and Clinical Immunology, vol. 133, no. 2, pp. 500-510, 2014.

[41] M. R. Karlsson, J. Rugtveit, and P. Brandtzaeg, "Allergenresponsive $\mathrm{CD} 44^{+} \mathrm{CD} 25^{+}$regulatory $\mathrm{T}$ cells in children who have outgrown cow's milk allergy," Journal of Experimental Medicine, vol. 199, no. 12, pp. 1679-1688, 2004.

[42] O. Palomares, G. Yaman, A. K. Azkur, T. Akkoc, M. Akdis, and C. A. Akdis, "Role of Treg in immune regulation of allergic diseases," European Journal of Immunology, vol. 40, no. 5, pp. 1232-1240, 2010.

[43] D. Mucida, N. Kutchukhidze, A. Erazo, M. Russo, J. J. Lafaille, and M. A. Curotto de Lafaille, "Oral tolerance in the absence of naturally occurring Tregs," Journal of Clinical Investigation, vol. 115, no. 7, pp. 1923-1933, 2005.

[44] Y. Belkaid and G. Oldenhove, “Tuning microenvironments: induction of regulatory T cells by dendritic cells," Immunity, vol. 29, no. 3, pp. 362-371, 2008.

[45] S. M. Schlenner, B. Weigmann, Q. Ruan, Y. Chen, and H. von Boehmer, "Smad3 binding to the foxp3 enhancer is dispensable for the development of regulatory $\mathrm{T}$ cells with the exception of the gut," Journal of Experimental Medicine, vol. 209, no. 9, pp. 1529-1535, 2012.

[46] C. Ma, Z. Ma, Q. Fu, and S. Ma, "Curcumin attenuates allergic airway inflammation by regulation of $\mathrm{CD} 4{ }^{+} \mathrm{CD} 25^{+}$regulatory T cells (Tregs)/Th17 balance in ovalbumin-sensitized mice," Fitoterapia, vol. 87, no. 1, pp. 57-64, 2013.

[47] H. Lee, H. Kim, G. Lee, H.-S. Chung, and H. Bae, "Curcumin attenuates lupus nephritis upon interaction with regulatory $\mathrm{T}$ cells in New Zealand Black/White mice," The British Journal of Nutrition, vol. 110, no. 1, pp. 69-76, 2013.

[48] S.-J. Yu and J. Tseng, "Fu-Ling, a Chinese herbal drug, modulates cytokine secretion by human peripheral blood monocytes," International Journal of Immunopharmacology, vol. 18, no. 1, pp. 37-44, 1996.

[49] T. Sanderson and M. van den Berg, "Interactions of xenobiotics with the steroid hormone biosynthesis pathway," Pure and Applied Chemistry, vol. 75, no. 11-12, pp. 1957-1971, 2003.

[50] D. Sliva, J. Loganathan, J. Jiang et al., "Mushroom ganoderma lucidum prevents colitis-associated carcinogenesis in mice," PLoS ONE, vol. 7, no. 10, Article ID e47873, 2012. 


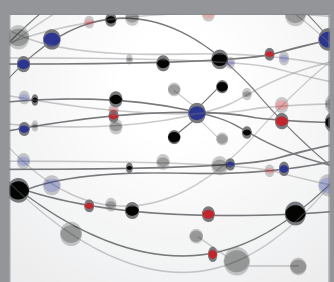

The Scientific World Journal
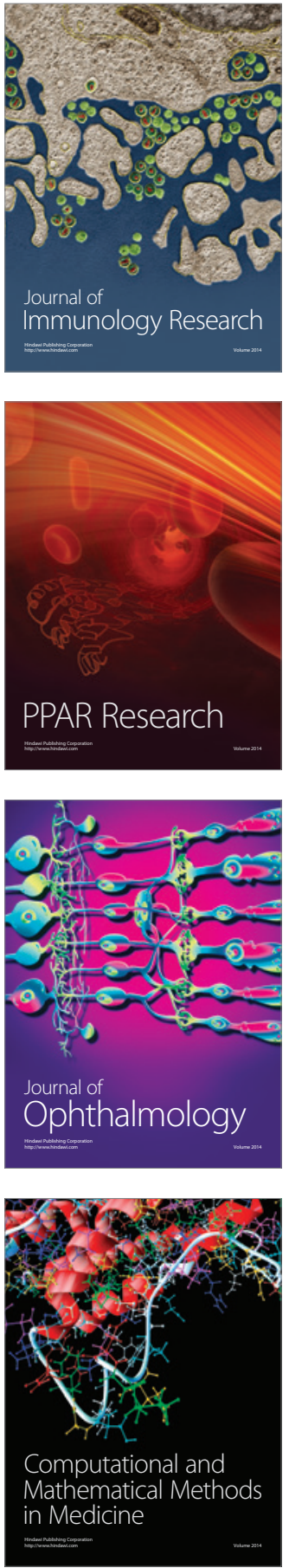

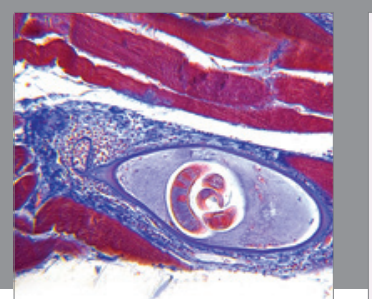

Gastroenterology Research and Practice

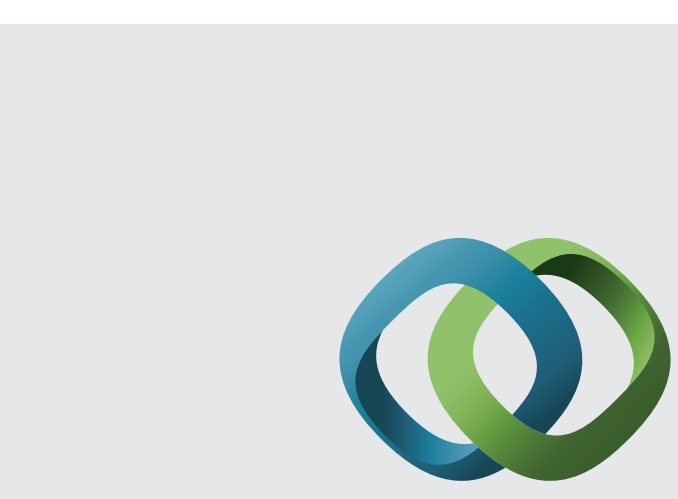

\section{Hindawi}

Submit your manuscripts at

http://www.hindawi.com
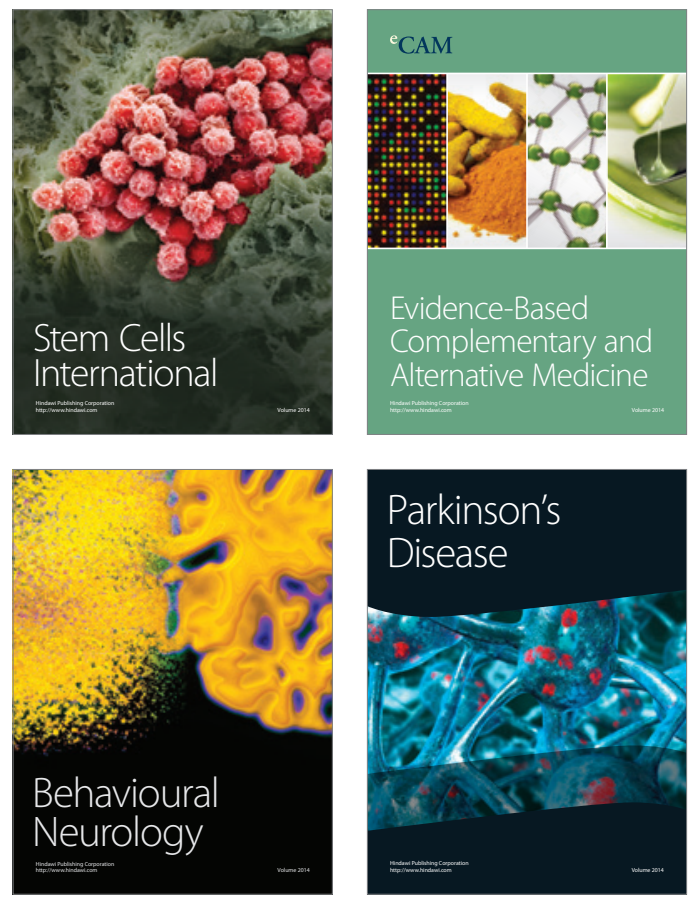
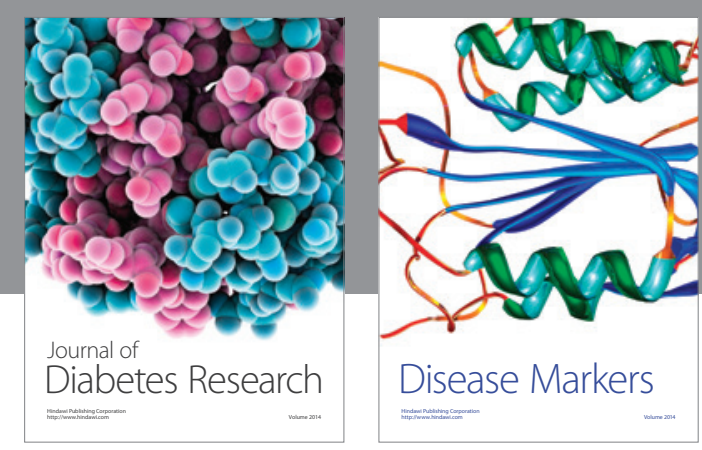

Disease Markers
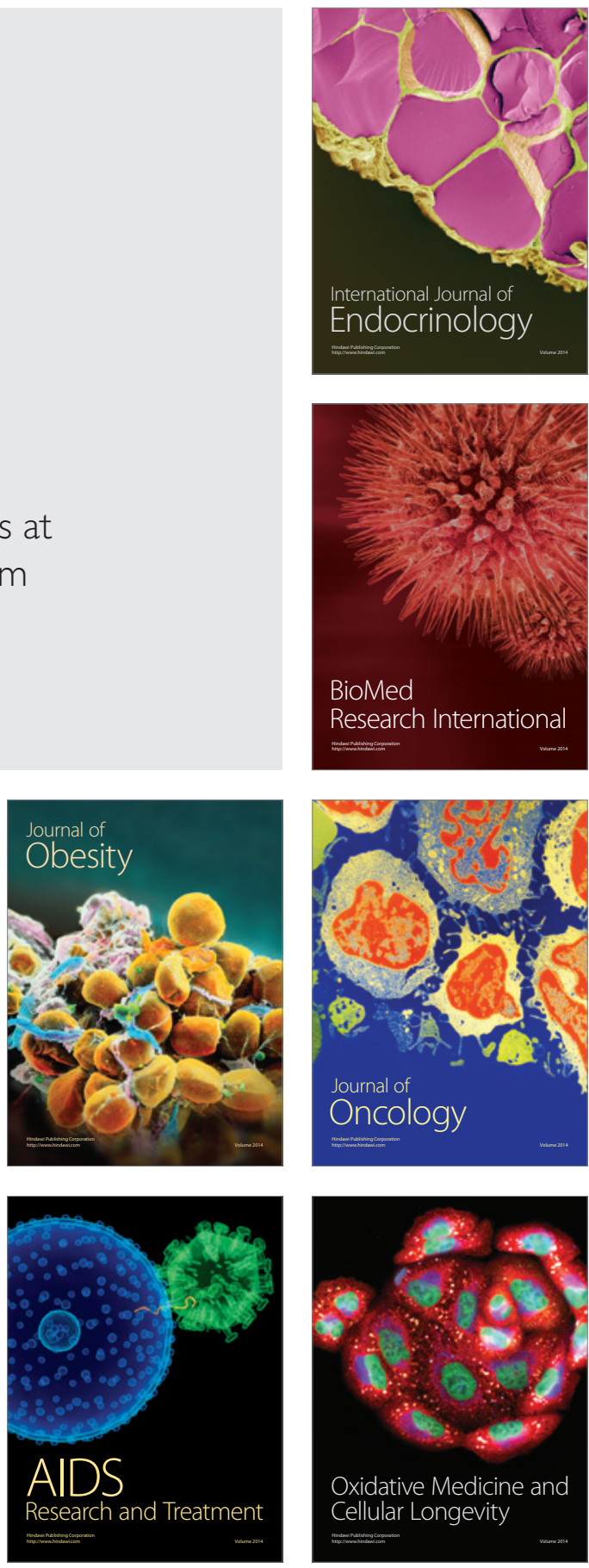